\title{
Soil erosion and sediment dynamics in the Anthropocene: a review of human impacts during a period of rapid global environmental change
}

\author{
Philip N. Owens ${ }^{1}$ (D) \\ Received: 21 July 2020 / Accepted: 20 October 2020 / Published online: 4 November 2020 \\ (C) The Author(s) 2020
}

\begin{abstract}
Purpose Humanity has been modifying the planet in a measurable way for thousands of years. Recently, this influence has been such that some feel we are in a new geological epoch, the Anthropocene. This review will describe how soil erosion and sediment dynamics have (i) been used to assess the impact of humans on the planet and (ii) affected the global climate and influenced water security. Emphasis is placed on changes since the middle of the twentieth century, as this coincides with what many suggest is the start of the Anthropocene Epoch.

Results and discussion The use of sediment archives has been instrumental in our understanding of how environmental systems have developed over time, both naturally and in response to anthropogenic activities. Additional information has come from measurement and monitoring programs, and tracing and fingerprinting studies. In turn, models have been developed that enable forecasting. Some of the main global impacts of enhanced soil erosion and changes in sediment dynamics and sediment composition include: changes in radiative energy balances and impacts on the cryosphere; the global carbon cycle; and greenhouse gas emissions. Impacts on water security include: effects on freshwater biota, including wild salmon populations; fluxes of contaminants, including microplastics; and reservoir and river channel sedimentation, including flooding. Sediment archives and monitoring programs have also been used to document the effect of mitigation measures and environmental policies.

Conclusion Sediment archives enable us to assemble information over a variety of timescales (i.e., $10^{0}$ to $10^{5}$ years and longer) and a range of spatial scales (from sub-watershed to continental), in addition to environments ranging from arid to tropical to polar. Often the temporal resolution is better than other paleoenvironmental reconstruction approaches. As such, sedimentary records, when combined with measurement and monitoring approaches and other sources of information, have enabled us to determine changes in atmospheric, terrestrial, and aquatic systems, especially over the last 100 years. While soil erosion and sediment dynamics have provided a wealth of information and greatly enhanced our understanding of the role of humanity in modifying the planet, suggestions are given for further research.
\end{abstract}

Keywords Sedimentarchives $\cdot$ Paleoenvironmental reconstruction $\cdot$ Sediment-associated contaminants $\cdot$ Cryosphere $\cdot$ Freshwater biota $\cdot$ Climate change

Responsible editor: David Allen Lobb

Philip N. Owens

Philip.owens@unbc.ca

1 Environmental Science Program and Quesnel River Research Centre, University of Northern British Columbia, Prince George, British Columbia V2N 4Z9, Canada

\section{Introduction}

We are now at a point in time where humanity is controlling how parts of the planet are functioning. In addition to altering the global climate, the actions of humanity are, among other things: altering the vegetation and land cover of the Earth's surface; regulating the flows of water, sediment, nutrients, and chemicals; modifying the height, composition, and $\mathrm{pH}$ of the global ocean; and causing the reduction and extinction of numerous biological species (Vitousek et al. 1997). Venter et al. (2016) estimate that $75 \%$ of the planet's land surface is 
experiencing measurable human pressure. Given this situation, one of the greatest challenges facing the scientific community is to identify the type and magnitude of the changes brought about by humanity on the environment.

For many people, sediment are considered a nuisance and typically have negative connotations. In most human systems, they are removed via sweeping (as in the case of the urban road network), filtering (as in the case of water supply systems), or dredging (as in the case of navigation channels). In environmental systems, they often have negative impacts, such as the smothering of river gravels or as a carrier of pollutants. But despite these apparent "problems" underlying all of these issues, and others, is the fact that sediment dynamics and composition provide a wealth of information about the state of the planet. While the emphasis of this paper is on sediment, they are strongly linked to soil erosion as this is often the primary source of this material and, therefore, both are considered. This review will describe how soil erosion and sediment dynamics and composition have (i) been used to assess the impact of humans on the planet and (ii) affected the global climate and influenced water security. The former objective focuses on approaches to assemble information and to assess the direction (i.e., increase vs decrease) and magnitude of the impacts. The latter objective focuses more on the nature of the impacts using examples, while also trying to illustrate the interconnectedness of the impacts. Inevitably, this review only covers some topics - which partly reflects the interests and experience of the author - and includes only a limited number of references, as there are thousands of published journal articles, book chapters, and reports by governments and other organizations on the subject matter. However, it is hoped that the material covered is sufficient to identify the role of sediment in understanding the impact of humanity on the planet and provides a platform for further reading.

\section{Reconstructing the history of humanity on the Earth using sediment}

Much of our understanding of the evolution of the planet has come from sedimentary records. Indeed, Lewis and Maslin (2018) call geologic sediment "Earth's natural storage devices." For example, Hays et al. (1976) used the oxygen isotope signal contained in planktonic foraminifera in 10 - to $15-\mathrm{m}$ cores of marine sediment dating back to $\sim 450,000$ years B.P. to reconstruct past climates. From this, they were able to confirm Milankovich's theory of orbital forcing which explained Quaternary glacial-interglacial cycles. Hays et al. (1976) suggested that it should be possible, therefore, to predict future "natural" climates, i.e., those in the absence of anthropogenic impacts. Interestingly, modeled predictions of future climate over the next several thousand years, but ignoring anthropogenic impacts, indicated extensive glaciation in the Northern Hemisphere (Hays et al. 1976). This helps to confirm the significant role of humans in modifying the present global climate system.

\subsection{Sediment and the Anthropocene}

In addition to facilitating the reconstruction of past climates, sedimentary records have also been used to identify and quantify the effects of humans on environmental systems. Thus, fossil charcoal and pollen preserved in sedimentary sequences have been used to establish the timing and magnitude of the use of fire, dated to the Early Pleistocene Epoch (Glikson 2013), and forest clearance for agriculture, which started about 11,000 years B.P. and became extensive about 8000 years B.P. (Lewis and Maslin 2015). Similarly, Roberts et al. (2018) used records of pollen contained in organic and minerogenic sedimentary deposits (e.g., bogs, lakes, etc.) for sites throughout Europe to show the temporal and spatial distribution of tree cover in Europe. For mixed temperate forest, the cover has been declining progressively since 6000 years ago linked to forest clearance for agriculture, while for boreal forests in northern Europe clearance has only become detectable in the last two millennia and is less widespread.

As such, sediment has been utilized for defining and dating the "Anthropocene," a new geological epoch in which the signal of humans is widespread and persistent and, in some cases, dominating as a geologic agent (Crutzen and Stoermer 2000; Crutzen 2002). Indeed, some have argued that to be a true, new geological epoch that "global-scale changes must be recorded in geological stratigraphic material such as glacier ice, rock or [terrestrial and] marine sediments" (Lewis and Maslin 2015, p. 171). While few would doubt that we are now in a new period of geological time, whereby humanity is strongly influencing most environments on the planet, there is much controversy over the timing of the start of the Anthropocene (Lewis and Maslin 2018; Ruddiman 2018). In this regard, sedimentary records contain a wealth of information (Table 1) that are likely to be valuable in how we determine and quantify the impact of humans on the planet. Waters et al. (2018) suggest that information contained in sediment deposits in certain marine, lacustrine, estuarine, and delta locations may contain the highest resolution stratigraphy to enable a globally synchronous marker to be established, a Global Boundary Stratotype Section and Point (GSSP) or so-called stratigraphic "golden spike" (Zalasiewicz et al. 2017).

While humans have impacted the planet for thousands of years, as described above, often the magnitude of the impacts was relatively small, in part due to low populations, and local. Impacts also tended to be diachronous as technological developments, such as land clearing, moved slowly between settlements separated over vast distances. It is argued that the start of the Anthropocene Epoch 
Table 1 Key events whereby humanity modified processes and environments on the Earth (modified from Lewis and Maslin 2015). Most lines of evidence include sediment in depositional environments like bogs/peat, wetlands, floodplains, lakes, and ocean (See Table 2 for a focus on the last 100 years)

\begin{tabular}{|c|c|c|c|}
\hline Event & Date & Geographic extent & $\begin{array}{l}\text { Stratigraphic markers and } \\
\text { lines of evidence }\end{array}$ \\
\hline Origin of farming & $\begin{array}{l}\sim 11,000 \text { years } \\
\text { B.P. }\end{array}$ & $\begin{array}{l}\text { Southwest Asia, } \\
\text { becoming global }\end{array}$ & $\begin{array}{l}\text { Fossil crop and tree pollen, } \\
\text { phytoliths, charcoal }\end{array}$ \\
\hline Extensive farming & $\begin{array}{l}\sim 8000 \text { years B.P. } \\
\text { to present }\end{array}$ & $\begin{array}{l}\text { Eurasia event, } \\
\text { becoming global }\end{array}$ & $\begin{array}{l}\mathrm{CO}_{2} \text { inflection in glacier ice, fossil } \\
\text { crop and tree pollen, phytoliths, } \\
\text { charcoal }\end{array}$ \\
\hline Rice production & $\begin{array}{l}\sim 6500 \text { years B.P. } \\
\text { to present }\end{array}$ & $\begin{array}{l}\text { Southeast Asian event, } \\
\text { becoming global }\end{array}$ & $\begin{array}{l}\mathrm{CH}_{4} \text { inflection in glacier ice, fossil } \\
\text { crop pollen, fossil domesticated } \\
\text { ruminant remains }\end{array}$ \\
\hline Anthropogenic soils & $\begin{array}{l}\sim 3000-500 \text { years } \\
\text { B.P. }\end{array}$ & $\begin{array}{l}\text { Local event, local } \\
\text { impact, but } \\
\text { widespread }\end{array}$ & $\begin{array}{l}\text { High organic matter content in } \\
\text { soils, fossil crop pollen }\end{array}$ \\
\hline $\begin{array}{l}\text { New-Old World } \\
\text { connection (i.e., } \\
\text { start of modern } \\
\text { world-system) }\end{array}$ & $1492-1800$ & $\begin{array}{l}\text { Eurasian-Americas } \\
\text { event, global impact }\end{array}$ & $\begin{array}{l}\text { Low point of } \mathrm{CO}_{2} \text { in glacier ice, } \\
\text { fossil pollen, charcoal, } \\
\text { phytoliths, speleothem } \delta^{18} \mathrm{O} \text {, } \\
\mathrm{CH}_{4}\end{array}$ \\
\hline Industrial revolution & 1760 to present & $\begin{array}{l}\text { Northwest Europe } \\
\text { event, local impact, } \\
\text { becoming global }\end{array}$ & $\begin{array}{l}\text { Fly ash from charcoal burning, } \\
{ }^{14} \mathrm{~N}:{ }^{15} \mathrm{~N} \text { ratio, and diatom } \\
\text { composition in lake sediments }\end{array}$ \\
\hline $\begin{array}{l}\text { Nuclear weapon } \\
\text { detonation }\end{array}$ & 1945 to present & $\begin{array}{l}\text { Local events, global } \\
\text { impact }\end{array}$ & $\begin{array}{l}\text { Radionuclides in tree rings, glacier } \\
\text { ice, and sediment deposits }\end{array}$ \\
\hline $\begin{array}{l}\text { Persistent industrial } \\
\text { chemicals }\end{array}$ & $\sim 1950$ to present & $\begin{array}{l}\text { Local events, global } \\
\text { impact }\end{array}$ & $\begin{array}{l}\text { Compounds in glacier ice and } \\
\text { sediment deposits }\end{array}$ \\
\hline
\end{tabular}

should be based on a clear, synchronous, and transformative stratigraphic signal (Zalasiewicz et al. 2017). Several markers have been used to help define the start of the Anthropocene and globally impactful radionuclide signals associated with thermonuclear weapon tests, such as plutonium-239 $\left({ }^{239} \mathrm{Pu}\right)$ and excess carbon-14 $\left({ }^{14} \mathrm{C}\right)$, are among the most useful (Waters et al. 2016). The timing of these tests, which started in the late 1940s and 1950s, coincides with the timing of the first occurrence of significant increases in other markers such as synthetic products (e.g., plastics, DDT) and the compounds and isotopes of carbon and nitrogen, such $\delta^{13} \mathrm{C}$ and $\delta^{15} \mathrm{~N}$, due to the combustion of hydrocarbons and the application of fertilizers (Waters et al. 2018) (Table 2; see also Section 3.2.2). The suggested timing of the start of the Anthropocene Epoch as the middle of the twentieth century also aligns with the Great Acceleration (Steffen et al. 2015), whereby substantial increases in socio-economic development-as measured using population growth, gross domestic product (GDP), energy consumption, paper production, and fertilizer application, etc.-mirrored changes in Earth system characteristics such as atmospheric chemistry and ocean acidification, among others.

\subsubsection{Sediment archives: changes in sediment fluxes and sedimentation rates}

In looking at sediment to record human activity on the planet, there are several types of evidence that can be used.
One type of evidence is changes in sediment fluxes on landscapes and in river systems and ultimately recorded in depositional environments like the ocean. Although there is a long history of such work (see Wohl 2020), especially within the discipline of geomorphology (e.g., Gilbert 1917), it increased in the 1950s (e.g., Leopold 1956; Thomas Jr 1956). Values of specific sediment yield (i.e., mass of material transported per unit time per unit contributing area) are often measured in transport corridors like rivers and provide a useful measure that integrates a range of processes occurring on the terrestrial/fluvial landscape (e.g., forms of erosion and sediment conveyance). Thus, studies have used terrestrial and oceanic sedimentary deposits and modern sediment yields in rivers to determine that global denudation rates due to natural processes are $~$ $5 \times 10^{9}$ t year $^{-1}$ (Wilkinson 2005). This value is important as it provides a baseline against which to compare more recent values, especially those since the middle of the twentieth century (i.e., the Anthropocene Epoch) and also to identify if management actions are having positive effects. Thus, the present rate of global denudation is $\sim 100$ $120 \times 10^{9}$ t year $^{-1}$ (Hooke 2000; Wilkinson 2005) (Fig. 1) It is important to remember that this value is reflective of weathering and erosion of the land surface due to a combination of natural processes and human activities, especially agriculture, resource extraction, and construction. Modern fluxes to the global ocean are of the order of 13$20 \times 10^{9}$ t year $^{-1}$ (Milliman and Syvitski 1992; Vörösmarty et al. 2003; Wilkinson and McElroy 2007; Milliman and 


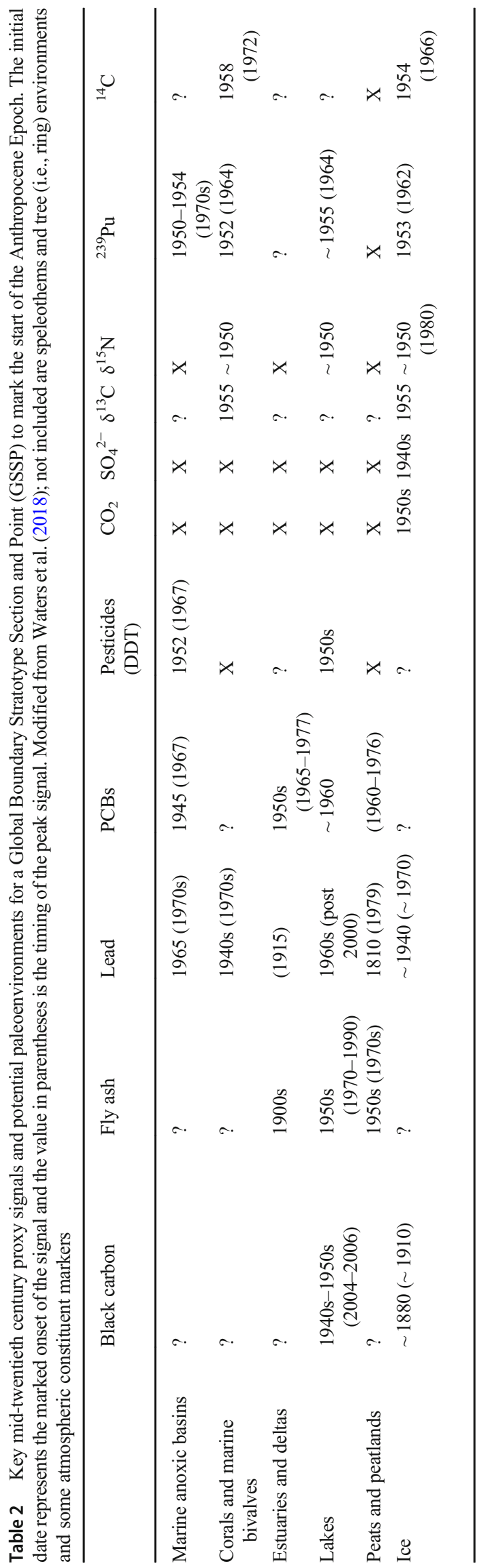

Farnsworth 2011; Li et al. 2020a) due to upstream storage, especially in reservoirs and on floodplains. Indeed, Syvitski et al. (2005) estimate that about $26 \%$ of the global terrestrial sediment flux (i.e., $>100 \times 10^{9}$ t; $1.4 \times$ $10^{9} \mathrm{t} \mathrm{year}^{-1}$ ) is stored in large and small reservoirs. The value now is likely larger given the addition of new reservoirs, such as that created by the completion of the Three Gorges Dam, China, in 2003, which had trapped over $2.6 \times 10^{9} \mathrm{t}$ of sediment up to 2015 (Wu et al. 2020). Thus, Milliman and Farnsworth (2011) estimate that the decrease in sediment discharge to the global ocean attributable to reservoirs may exceed $5 \times 10^{9} \mathrm{t}_{\text {year }}{ }^{-1}$. Similarly, Li et al. (2020a) assessed suspended sediment fluxes for 309 of the world's large rivers (basin area > $1000 \mathrm{~km}^{2}$ ) and determined that the sediment flux to the global ocean has decreased by $\sim 20 \%$ over the last 5 10 years compared to the longer-term average. They identified that this was mainly due to reservoir sedimentation, especially in Asian rivers, as well as soil conservation practices (see also Section 3.2.3).

Other studies have used a paleoenvironmental reconstruction approach to determine local and regional changes in erosion and sediment fluxes in response to land cover and land use changes (e.g., Oldfield 1977; Dearing 1991; Page and Trustrum 1997; Zolitschka 1998). In many situations, the records show that sediment yields - and by inference rates of erosion and sediment delivery - have increased over the last 100 years, and especially since the middle of the twentieth century. In some cases, this is due to agricultural intensification following World War II and, in particular, the conversion of pasture to arable land and increases in stocking density (e.g., Foster and Lees 1999; Walling et al. 2003a). In other cases, it reflects land conversion since the 1960s, such as deforestion in the Mara River basin in Kenya and Tanzania (Dutton et al. 2019). While individual casestudy examples are informative - as often the detail and resolution of the sediment records are of a high levelsuch studies may be unable to determine if an impact is due to a localized activity (e.g., a mine or single farm activity) or is of regional or global significance (e.g., due to regional/national policies or climate change). At the regional and (multi-)national scale, large numbers of depositional environments are required to capture the full spatial extent of changes. Thus, Schiefer et al. (2013) used dated cores from 104 lakes in western Canada (British Columbia and Alberta), and mixed-effects modeling, to allocate trends in sedimentation to changes in climate and land use. They found that wide-scale forest harvesting and associated road infrastructure, mainly since the middle of the twentieth century, explained much of the increases in sedimentation. This is covered more in the next section. 
Fig. 1 Historical rates of anthropogenic erosion and the long-term (i.e., last $\sim 541$ million years) geologic denudation rate (24 m per million years)

(modified from Wilkinson 2005)

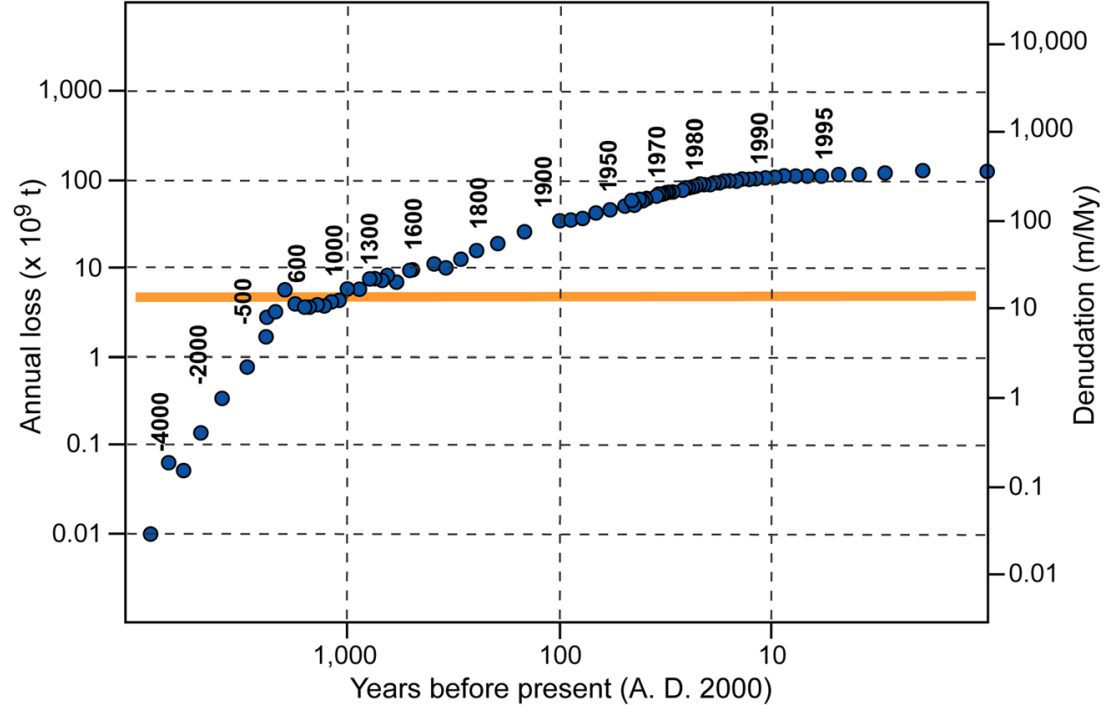

\subsubsection{Sediment archives: changes in sediment composition and properties}

Fossil pollen records have long been used to reconstruct past climates and vegetation composition, including the impact of humans, as described earlier (Section 2.1). In many cases, such records are linked to changes in sedimentation rates, which provide a measure of rates of soil erosion and sediment delivery to the receiving waterbody; useful reviews are provided by Dotterweich (2013) and Vanwalleghem et al. (2017). Thus, Jenny et al. (2019) reconstructed sediment accumulation rates for 632 lakes throughout the world to infer the start of anthropogenic soil erosion. They showed that rates of sediment accumulation had increased prior to 4000 years B.P. and this increase was linked to decreases in arboreal pollen due to the conversion of forested land to agriculture. Interestingly, Jenny et al. (2019) were also able to identify increases in sediment accumulation rates and arboreal pollen in the early Holocene (ca. 12,000 to 8000 years B.P.) due to the recession of the Northern Hemisphere ice sheets (i.e., paraglacial sedimentation; Church and Ryder 1972) and the subsequent stabilization of landscapes between ca. 8000 to 4000 years B.P.

The chemical composition of sediment has also been used to reconstruct the impacts of humans on the environment. For example, the concentrations of trace elements recorded in wetland, floodplain, lake, and estuarine sediment deposits have been used to record the start of industrialization and associated pollution of terrestrial and aquatic systems, often over thousands of years, as in the case of mercury (e.g., MartínezCortizas et al. 1999; Cooke et al. 2009, 2020) and other metals (Hudson-Edwards et al. 1999; Elbaz-Poulichet et al. 2020) that have a long history of mining (Fig. 2). Recently, similar studies have used sediment deposits to document the pollution of aquatic systems from artificial substances. Thus, Thiebault et al. (2017) used cores of sediment collected behind a dam in the city of Orleans, France, to document the occurrence of pharmaceutical products, such as painkillers (e.g., acetaminophen) and antibiotics (e.g., ofloxacin), over the last 50 60 years. They demonstrated that the first occurrence of the pharmaceutical products in the sediment typically coincided with the introduction of the product on the market (also see Section 3.2.2). They were also able to use downcore profiles of the concentrations of pharmaceutical products in the sediment to infer human behavior via the management operations of nearby wastewater treatment plants.

\subsubsection{Sediment flux monitoring}

There are several contemporary measurement and monitoring approaches that can be utilized to assess the impacts of humans on soil erosion and sediment dynamics. In the case of soil erosion and redistribution, this includes: (i) measuring specific erosion processes over time (e.g., use of erosion pins, erosion bridge, erosion plots; Shakesby 1993; Lawler et al. 1999; Poesen 2018); use of a series of maps or remote sensing images (e.g., Welch et al. 1984; D'Oleire-Oltmanns et al. 2012); and the use of tracers such as fallout radionuclides (e.g., Guzman et al. 2013; see Section 2.1.4). In the case of sediment fluxes in rivers, numerous countries have a network of gauging stations that measure discharge and sometimes suspended sediment fluxes. The latter is usually determined by measurements of suspended sediment concentration, often estimated via continuous turbidity measurements, which are converted to suspended sediment loads and yields using discharge records. Some stations also measure bedload yields although such stations are less common given the inherent difficulty of measuring bedload. Although records of suspended sediment flux typically only cover periods of several decades, in some cases, there are essentially continuous 
Fig. 2 Total accumulation rates $\left(\mathrm{AR}_{\mathrm{T}}\right)$ and enrichment ratios $(\mathrm{EF})$ for copper $(\mathrm{Cu})$, antimony $(\mathrm{Sb})$, mercury $(\mathrm{Hg})$, and lead $(\mathrm{Pb})$ in cores collected from Lake Robert, France. Sediment levels older than 10,800 years $\mathrm{BC}$ could not be dated and were thus assigned arbitrary dates (modified from Elbaz-Poulichet et al. 2020)

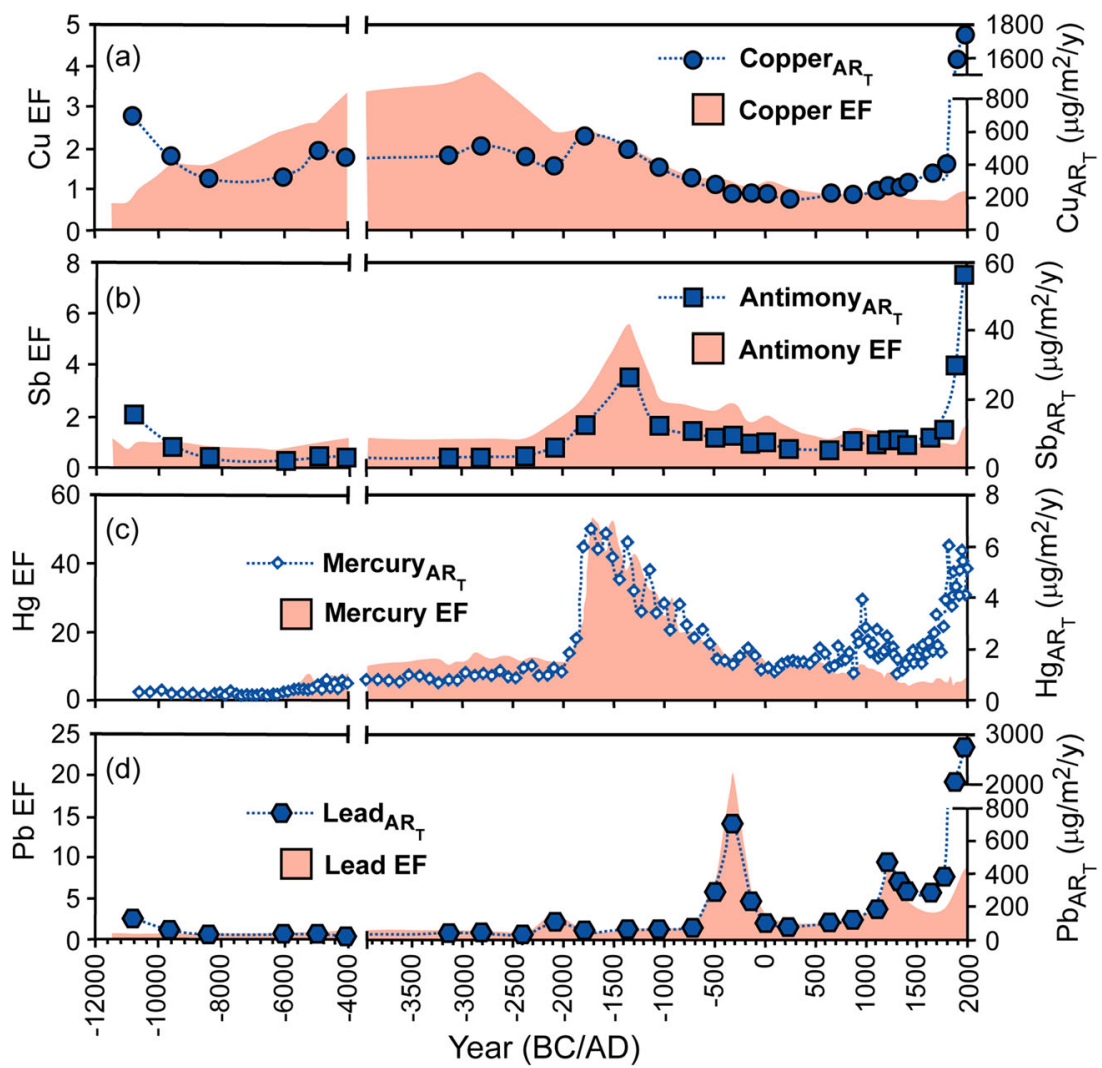

records that go back $50-100$ years. In these cases, it is possible to examine the role of numerous factors on sediment fluxes (e.g., land use and climate changes; see examples above) including mitigation practices. For example, Li et al. (2020b) reconstructed the history of sediment fluxes in the Mississippi River, USA, from 1952 to 2009 (Fig. 3), using records of discharge and suspended sediment concentration from the US Geological Survey. Sediment fluxes to the coastal zone have decreased from $400-500 \times 10^{6}$ t year $^{-1}$ prior to 1900 (see Horowitz 2010; Meade and Moody 2010) to $\sim 350 \times$ $10^{6} \mathrm{t}^{\text {year }^{-1}}$ for the period 1952-1962 and to $\sim 200 \times$ $10^{6}$ t year $^{-1}$ for $1963-2009$. Li et al. (2020b) estimate that this reduction is due to soil conservation measures and sediment being trapped behind dams; Meade and Moody (2010) also identify the effect of river engineering. The result of this considerable reduction in suspended sediment load to the lower reaches of the river - including the city of New Orleans - and the Gulf of Mexico has been profound, particularly as it coincides with sea-level rise. It is estimated that $5000 \mathrm{~km}^{2}$ of the Louisiana coastline alone has been lost over the last 80 years due to coastal erosion. Consequently, the state of Louisiana has pledged US $\$ 50$ billion to help stop coastal erosion, including returning upstream sediment fluxes and dynamics to more natural conditions (Globe and Mail 2019).
Fig. 3 Interannual variability of sediment flux to coastal Louisiana, the Gulf of Mexico, from the Mississippi River system, USA (modified from Li et al. 2020b). The record is divided into two periods (1952-1962 (P1) and 1963-2009 (P2)) due to an abrupt change point in 1962 (for details, see Li et al. 2020b)

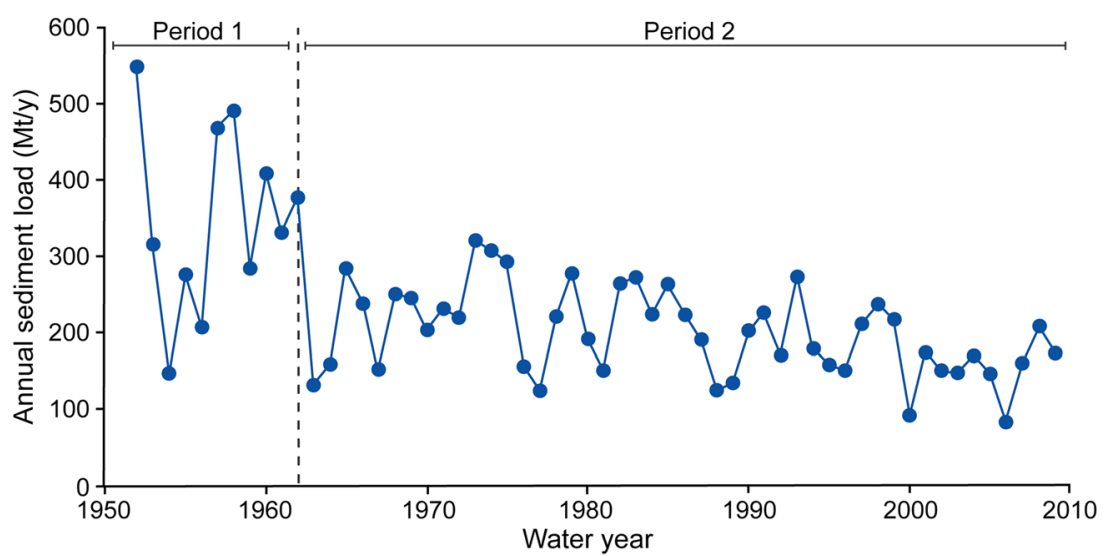




\subsubsection{Sediment tracing and fingerprinting}

In addition to direct measurement and monitoring of sediment fluxes, studies have also used tracers to assess the role of humans on the planet. Fallout radionuclides (FRNs), such as unsupported lead-210 $\left({ }^{210} \mathrm{~Pb}_{\text {un }}\right)$, cesium-137 $\left({ }^{137} \mathrm{Cs}\right)$, and beryllium-7 ( $\left.{ }^{7} \mathrm{Be}\right)$, have been used to estimate rates of soil erosion and sediment redistribution, particularly on agricultural land (Mabit et al. 2008). One of the main advantages of the use of FRNs like ${ }^{137} \mathrm{Cs}$ is that they can be used in most parts of the world given their global distribution, thereby providing a common approach and enabling rates of soil erosion and sediment redistribution, and identification of sediment sources, to be compared (Mabit et al. 2008; Evrard et al. 2020). Some studies (e.g., Khodadadi et al. 2019) have used FRNs with different radioactive half-lives to assess changes in erosion and redistribution over time or evaluate the effectiveness of soil conservation measures (Dercon et al. 2012). Other studies (e.g., Tiessen et al. 2009; Li et al. 2011; Porto et al. 2018) have resampled the activity inventories of FRNs at the same site after a period of time (i.e., decades) to assess to impact of land use changes and management on rates and patterns of soil erosion and sediment redistribution. Studies have also used other sediment tracers, such as rare earth elements and mineral magnetic substances (for a review, see Guzman et al. 2013).

Sediment tracers have also been used to document where sediment originated from, by using a suite of tracers to "fingerprint" the main sediment sources. While such information is useful for understanding how natural landscapes have evolved over time, most work has focused on aquatic systems where sediment have been identified as a problem; for example, the delivery of excessive nutrients (e.g., phosphorus) and contaminants; issues of the reservoir or channel sedimentation; or impacts on sensitive aquatic ecosystems (see Section 3.2). The majority of studies have determined the sources of contemporary sediment by collecting samples of suspended sediment or the sediment temporally stored in the channel bed (for reviews, see Walling 2013; Haddadchi et al. 2013; Owens et al. 2016; Collins et al. 2017). Often, such an approach is part of a larger sediment measurement and monitoring network (e.g., Walling et al. 1999), such as the work to investigate sediment fluxes to the Great Barrier Reef in Australia (for a review, see Bartley et al. 2014), while in other cases it is a bespoke sampling campaign to address a specific issue, such as a wildfire (e.g., Smith et al. 2011; Owens et al. 2012; García-Comendador et al. 2017). In some situations, the sediment fingerprinting technique has been used with sediment archives to reconstruct changes over time (e.g., Collins et al. 1997; Owens et al. 1999; Owens and Walling 2002; Walling et al. 2003a; Wynants et al. 2020). Thus, Gateuille et al. (2019) applied the sediment fingerprinting technique to a floodplain core to reconstruct changes in the dominant sediment sources in a large drainage basin in British Columbia,
Canada, following the construction of a dam and reservoir in the 1950s, and subsequent land use changes (Fig. 4). In the context of assessing the role of humanity on the planet, using the sediment fingerprinting technique to reconstruct changes in sediment sources and dynamics over time offers great potential as it is able to identify trends and avoids some of the limitations associated with sampling over a limited period, such as a year or two (for a useful review, see D'Haen et al. 2012). Such an approach is particularly powerful when linked to additional information in sediment archives such as pollen and other proxies of environmental conditions, and historical information on drivers such as changes in land use/land cover and climate.

\subsection{Use of models to predict the future: addressing sediment connectivity in model structures}

The understanding of the Earth obtained using sediment archives, measurement, and monitoring programs, and tracing and fingerprinting techniques can be used to predict the Anthropocene of the future. Numerical models probably represent the best way to achieve this. There is a vast literature on the use of models to estimate contemporary rates and patterns of soil erosion (e.g., see Merritt et al. 2003; Brazier 2004; Van der Perk et al. 2008; Pandey et al. 2016; Batista et al. 2019) and the reader is directed to these sources of information. Some studies have used models to predict the situation in the future. Thus, Borrelli et al. (2020) used a high-resolution version of the Revised Universal Soil Loss Equation (RUSLE)-based semi-empirical modeling approach (GloSEM) to predict changes in soil loss by some water erosion processes (mainly rill and inter-rill erosion) using a variety of Shared Socioeconomic Pathway and Representation Concentration Pathway (SSP-RCP) scenarios. Borrelli et al. (2020) were able to investigate the effects of changes in land use, conservation measures, and climate on global soil erosion rates for 2070. While socio-economic developments caused increases or decreases in erosion relative to values in 2015, depending on the scenario, in all cases, climate change projections increased water erosion rates $(+30 \%$ to $+66 \%)$, especially under the RCP 8.5 greenhouse gas emission scenario. One can imagine that projections of soil loss estimates might be greater if all forms of water erosion, in addition to other forms of soil mobilization and erosion (e.g., tillage, wind, coextraction with crops and farm machinery etc.) were considered. This highlights a need for models which are able to address all soil mobilization and erosion processes.

Several studies have used models to predict how sediment fluxes may respond to future: (i) changes in land use/land cover; (ii) use of watershed beneficial management practices (BMPs); and (iii) changes in climate. The Soil and Water Assessment Tool (SWAT; Arnold et al. 1998) represents one of the most widely used models for this purpose, in part 
a

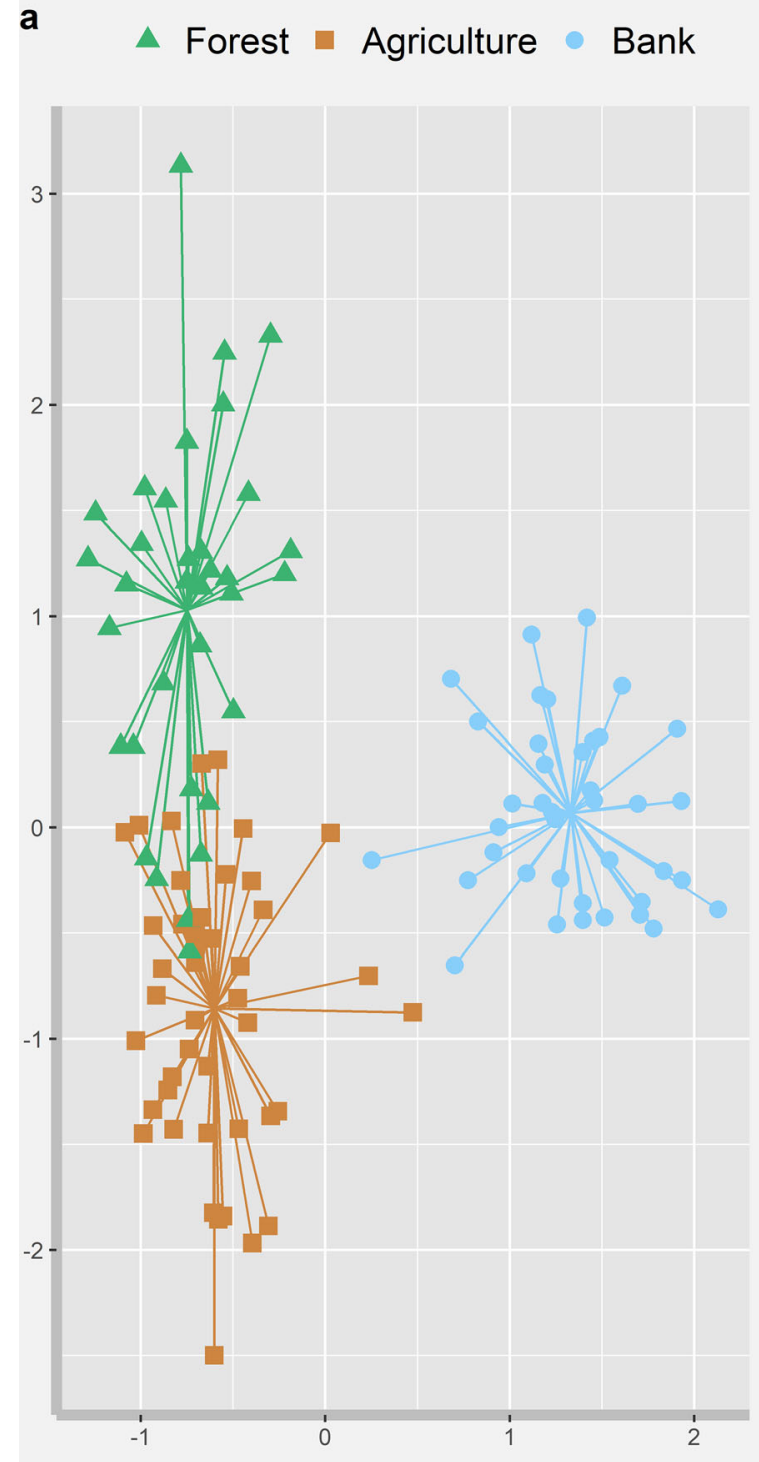

Fig. 4 a Results of discriminant function analysis used to distinguish the three main sources of fine-grained sediment in the Nechako River basin, British Columbia, Canada; and $\mathbf{b}$ downcore variations in source contributions for a floodplain core. Variations in sources reflect the construction

because of its ease of use and because it can be adapted for use outside of its original land use/land cover type (i.e., agricultural lands). Often, the model is used to assess recent changes following land use/land cover changes including soil conservation measures (e.g., Melaku et al. 2018) or likely changes in future sediment fluxes due to climate change using an ergodic approach (e.g., Palazón and Navas 2016), which in turn have forecasting implications. Other models which link soil erosion with sediment dynamics at the watershed scale include the SEdiment Delivery Distributed model (SEDD; Ferro and Porto 2000), the SEdiment DElivery Model (SEDEM; Van Rompaey et al. 2001), the linked Water and Tillage Erosion Model (WaTEM)-SEDEM model (Verstraeten and Prosser 2008), and the Sediment river Network model and its b

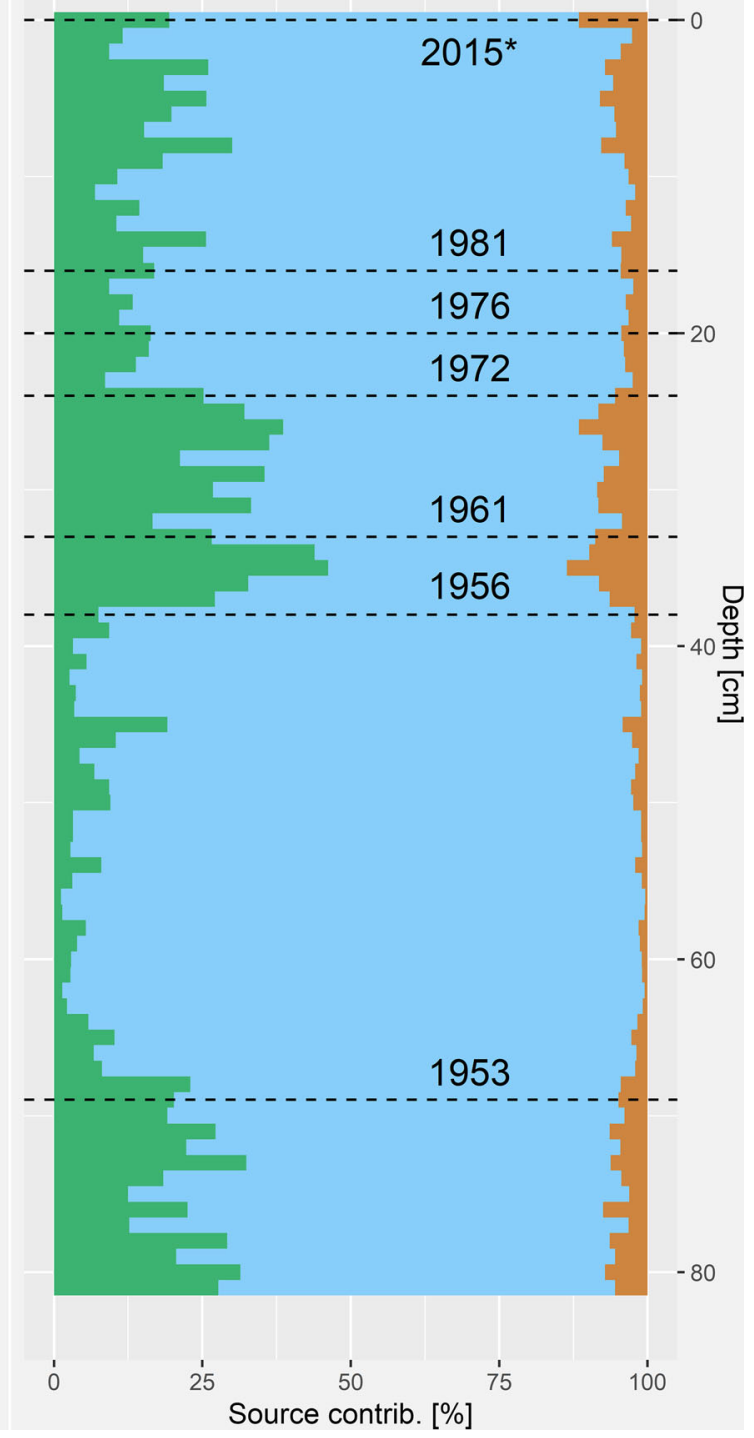

of a dam and creation of a reservoir in the 1950s, as well as changes in land use (mainly forestry activities and expansion of agriculture) in addition to wildfires and pine beetle outbreaks (modified from Gateuille et al. 2019)

derivatives (e.g., D-SedNet; Wilkinson et al. 2014). Some studies have used climate scenarios based on global circulation models to predict future changes in soil erosion and sediment transport (e.g., Asselman et al. 2003). Thus, Bussi et al. (2014) used the distributed land surface model TETIS to predict sediment yields in a mountainous catchment in Spain for the period 2071-2100 based on two different greenhouse gas emission scenarios. Relative to a control period (1961-1990), sediment yields increased for one scenario (local conditions) but decreased in the other which was representative of regional projected climatic conditions.

In most cases, there still remain large uncertainties associated with the predictions made by models (Batista et al. 2019; Baartman et al. 2020), particularly for those concerned with 
routing sediment through large and/or complex watersheds. One of the main reasons for this relates to the representation of connectivity within models (Keesstra et al. 2018). The concept of connectivity in understanding the routing of water and sediment in landscapes has received much attention over the last 15 years (e.g., Brierley et al. 2006; Bracken and Croke 2007; Fryirs et al. 2007; Borselli et al. 2008; Bracken et al. 2013, 2015; Fryirs 2013; Keesstra et al. 2019; Poeppl et al. 2020) (for a useful review on sediment connectivity, see Najafi et al. 2020). Conceptually, it is useful to consider sediment connectivity as a combination of structural and functional components (Wainwright et al. 2011), where the former relates to the configuration of landscape elements, and the latter addresses process dynamics. Keesstra et al. (2018) have identified that a problem with this approach in models of soil erosion and sediment routing is that structural connectivity tends to view landscape topography as essentially static over time, whereas over medium to long time scales this may not be true, especially as humans modify the landscape. Instead, Keesstra et al. (2018) advocate that water and sediment connectivity should be considered in terms of time-independent and time-variant properties. Thus, new developments in the incorporation of sediment connectivity concepts into watershed scale erosion and sediment routing models (e.g., Baartman et al. 2020; Mahoney et al. 2020a, 2020b) offer exciting opportunities to improve the ability of models for forecasting.

\section{Impacts of soil erosion, sediment dynamics, and sediment composition on the global climate and water security}

The previous sections have demonstrated that information contained in sediment archives (i.e., terrestrial and marine) and an understanding of recent and contemporary sediment dynamics and composition represent comprehensive ways to determine how humanity has impacted the planet over a range of timescales. The following sections consider some of these main impacts in more detail, with an emphasis on contemporary global environmental issues.

\subsection{The role of soil erosion, sediment dynamics, and sediment composition on the global climate}

There are several ways in which soil erosion and sediment dynamics have contributed to global climate change. These include the role of soil erosion in modifying vegetation cover and its subsequent effect on, for example: (i) the hydrological cycle (e.g., transpiration, evaporation, runoff); (ii) soil-atmosphere gas exchanges (including greenhouse gases); and (iii) heat exchanges by altering surface albedo. Similarly, sediment transport has also greatly affected the global climate, either directly or indirectly as a vector for redistributing substances, such as carbon. The following sections will examine this topic further using three examples.

\subsubsection{Effect of atmospheric particulates on radiative energy balances and impacts on the cryosphere}

Particulate materials in the atmosphere, such as aerosols and dust, influence the global climate directly through radiation balances and cloud formation, and indirectly through ocean fertilization which alters carbon sequestration (Mahowald et al. 2005; McConnell et al. 2007a). Mahowald et al. (2005) estimated that the total global dust flux is $1800 \times 10^{6} \mathrm{t} \mathrm{year}^{-1}$ and this represents about $14 \%$ of the annual global flux of sediment to the oceans (Derry and Chadwick 2007). A significant portion of atmospheric dust is derived from processes on the land surface ("crustal dusts"; McConnell et al. 2007a), such as volcanic activity, biomass burning, weathering, and wind erosion of fine-grained sediments from deserts, agricultural land (e.g., exposed and recently tilled land), urban areas, and resource extraction activities (e.g., mines). Thus, it is estimated that $182 \times 10^{6} \mathrm{t}$ of dust is derived from the Sahara desert in Africa each year due to wind erosion; interestingly, this source supplies 22,000 $\mathrm{t}_{\text {year }}{ }^{-1}$ of phosphorus to the Amazon basin, thereby fertilizing rainforests (Yu et al. 2015).

Studies have shown that atmospheric dust levels have increased over the last 100 years or so in response to human activity. Thus, McConnell et al. (2007a) investigated "crustal dust" in ice core records from the northern Antarctic Peninsula and determined that deposition fluxes increased from an annual average of $12 \mathrm{mg} \mathrm{m}^{-2}$ year $^{-1}$ for $1832-1900$ to $27 \mathrm{mg} \mathrm{m}^{-2}$ year $^{-1}$ for 1960-1991. They assert that the increase in atmospheric dust levels in Antarctica partly reflects land use changes such as overgrazing and deforestation in South America.

In addition to modifying radiation balances in the atmosphere, atmospheric dust can also influence the global climate when it is deposited on the Earth's surface. For example, changes in surface albedo (i.e., reflectivity) influence the amount of incoming solar energy that is either reflected back into the atmosphere or absorbed by a surface. It is probably true to say that cryospheric environments are the most sensitive to such changes. Small changes in albedo can cause snow, glaciers, ice sheets, and permafrost to melt at enhanced rates, which can lead to a variety of subsequent effects including changes in hydrological and geomorphological processes, and associated issues for downstream water resources. In many cases, this can cause a positive feedback loop, with increased melting of snow, ice, and permafrost causing the release of greenhouse gases into the atmosphere (see Section 3.1.3). Recent studies (e.g., Wittmann et al. 2017; Yue et al. 2020) have identified that the deposition of dark, 
particulate material (i.e., fine-grained organic and minerogenic sediment) on cryospheric surfaces can have measurable effects on albedo, thereby changing the surface radiation balance. Thus, Neto et al. (2019) showed that recent biomass burning in the Amazon Basin resulted in the deposition of particulate material on Andean glaciers, causing a change in surface albedo and an increase in glacier melt. They calculated that a combination of black carbon and atmospheric minerogenic dust (i.e., $100 \mathrm{ppm}$ in surface snow/ice) could decrease surface albedo by up to $20 \%$.

While much attention has been given to the role of black carbon due to the burning of biomass and fossil fuels, which accelerated with the start of the industrial revolution (e.g., Flanner et al. 2007; McConnell et al. 2007b), recently, there has been a recognition of the important role of airborne particulates derived from wildland fires on the cryosphere (Keegan et al. 2014), as well as other parts of the planet. In part, this is because of the increase in extreme wildfires in the last decade or so-itself a probable consequence of global warming (Westerling 2016) - and the use of fire to clear vast amounts of land for large-scale agriculture and plantations (e.g., Indonesia in 2015, Brazil in 2019 and 2020). In these situations, the particulates are both organic (i.e., from burning of the biomass) and minerogenic due to the exposure of burnt soils and sediments to wind erosion processes (Whicker et al. 2006; Wagenbrenner et al. 2011).

Interestingly, studies have shown that increases in glacier melt — due to increases in air temperatures and deposition of atmospheric particulates - can cause increases in sediment delivery to, and sediment transport in, downstream rivers (Moore et al. 2009; Milner et al. 2017). In turn, glacial melt is likely to release contaminants and pathogens, such as bacteria and viruses, previously stored in glacial ice (e.g., Blais et al. 1998, 2010; Owens et al. 2019a), a phenomenon also associated with thawing permafrost (Vonk et al. 2015; Houwenhuyse et al. 2018). This may have implications for downstream aquatic environments and water resources (Fig. 5). In turn, the exposure of new surfaces in proglacial areas and the release of sediment due to glacial retreat will provide new sources of material for wind erosion, thereby contributing to airborne particulates.

\subsubsection{Effects on the global carbon balance}

One of the main ways in which soil erosion and sediment transport have contributed to global climate change is by their influence on the movement and sequestration of carbon. Numerous studies (e.g., Stallard 1998; Lal 2003; Van Oost et al. 2007) have attempted to determine the role of soil erosion by water on the terrestrial carbon cycle and, in particular, if soil erosion and sediment redistribution cause a net carbon sink or source. Early work by Stallard (1998) used an ensemble of model scenarios to estimate that human-induced burial of carbon on land was $0.6-1.5 \mathrm{Pg} \mathrm{C}_{\text {year }}{ }^{-1}\left(\mathrm{P}=1 \times 10^{15}\right.$; thus, $0.6-1.5 \times 10^{9}$ t of $^{C}$ year $^{-1}$ ). Lal (2003) extended this work to estimate that the amount of soil organic carbon (SOC) translocated by water erosion was in the range 4.0-6.0 Pg C year $^{-1}$, of which 2.8-4.2 Pg C year ${ }^{-1}$ was redistributed and transferred to depressional sites for burial and/or transformation. The amount transported by rivers, either dissolved or associated with sediments, to the global ocean was estimated to be $0.4-0.6 \mathrm{Pg} \mathrm{C}_{\text {year }}{ }^{-1}$; this carbon may be mineralized or buried with marine sediments. The remainder (i.e., $0.8-1.2 \mathrm{Pg}$ $\mathrm{C}$ year ${ }^{-1}$ ) is emitted into the atmosphere. Other studies have determined different values for the global carbon cycle. Thus, Van Oost et al. (2007) estimated total agricultural SOC erosion rates of 0.47-0.61 $\mathrm{Pg} \mathrm{C}_{\text {year }}{ }^{-1}$; Borrelli et al. (2013) have revised this gross $\mathrm{SOC}$ displacement to $\sim 0.8 \mathrm{Pg} \mathrm{C}_{\mathrm{Cear}}{ }^{-1}$ (i.e., $36 \%$ of the $2.5 \mathrm{Pg} \mathrm{C}$ year $^{-1}$ total due to water erosion on land). Van Oost et al. (2007) also calculated that soil erosion in the world's agricultural landscapes resulted in a global carbon sink of 0.12 (range $0.06-0.27$ ) Pg C year ${ }^{-1}$ and that 16-21 $\mathrm{Pg}$ of carbon has been buried in agricultural landscapes over the past $\sim 50$ years.

Other studies have identified the important role of reservoirs in storing, sequestering, and mineralizing carbon. Thus, Syvitski et al. (2005) estimated that $1-3 \times 10^{9}$ t of carbon (i.e., 1-3 Pg C year ${ }^{-1}$ ) has been sequestered in reservoirs mainly over the last $\sim 50$ years. Other parts of the landscape where sediment are deposited and stored, such as floodplains, wetlands, lakes, and estuaries, are also likely to contain significant amounts of carbon. In these situations, the carbon is likely to be buried and/or transformed. In other aquatic environments, such as channel beds and riverine slack-zones, the storage of carbon is likely to be short-term, with minimal net loss to the system (i.e., sequestration). These environments may be more important in terms of carbon transformations, as in the case of aquatic biofilms (Battin et al. 2008). However, our understanding and representation of lateral fluxes of carbon from the land, through freshwater systems, to the global ocean in the Land - Ocean Aquatic Continuum (LOAC) is generally lacking in most global carbon and climate models (see Flato et al. 2013; Le Quéré et al. 2018).

\subsubsection{Effects of thawing permafrost on greenhouse gas emissions}

In the examples above, anthropogenic activities have caused changes in erosion and sediment transport which have directly affected the global climate via atmospheric particulates and the redistribution of carbon. This is particularly relevant to areas that have experienced agricultural, forest harvesting and resource extraction activities. Furthermore, these land use activities, among others (i.e., industrialization and urbanization) result in the release of greenhouse gases, which also directly affect the global climate; this is beyond the scope of 


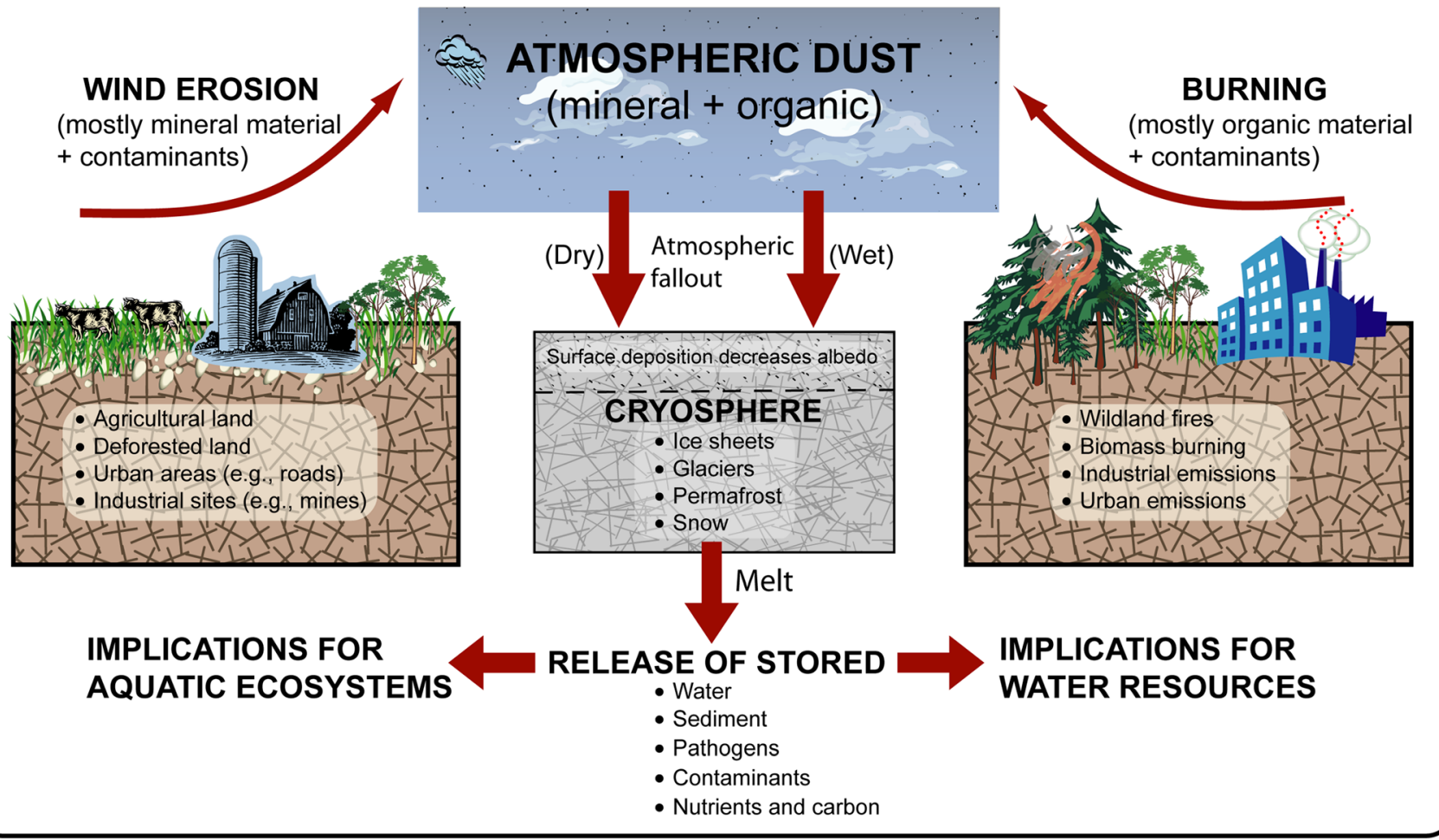

Fig. 5 Link between atmospheric dust derived from human activities, melt of the cryosphere, and downstream impacts on aquatic ecosystems and water resources

this review and the reader is directed to other publications (e.g., Duxbury 1994; Robertson et al. 2000; Kalnay and Cai 2003; Myhre et al. 2013). In these cases, the link is between: (i) human-induced changes in land cover/land use; (ii) subsequent changes in soil erosion, and sediment dynamics and composition; and (iii) changes in climate. Often there is a positive feedback loop such that human-induced changes in climate result in further changes in land cover/land use, and so on. In some landscapes, the link is a more direct one between: (i) human-induced changes in climate; and (ii) subsequent changes in erosion, and sediment dynamics and composition. In other words, there need not be direct modification of land cover/land use by humans. Examples of this simpler situation include unmanaged landscapes such as certain tropical forests, grasslands, and the cryosphere, such as permafrost. Again, the link typically causes a positive feedback loop, such that modified geomorphological processes result in further changes in the global climate.

Permafrost - ground that is at or below $0{ }^{\circ} \mathrm{C}$ for 2 years or more and includes frozen peat, soil, and sediment —occupies about $25 \%$ of the land surface of the Northern Hemisphere, mainly in Alaska (USA), Canada, Russia, and Scandinavia. The rate of surface air warming occurring in the high latitudes of the Northern Hemisphere (i.e., the Arctic) is approximately double the global average. Consequently, permafrost is melting and in turn releasing huge quantities of greenhouse gases, including carbon dioxide $\left(\mathrm{CO}_{2}\right)$, methane, and nitrous oxide, which were previous stored. For example, Schuur et al. (2015) report that terrestrial permafrost (i.e., not including sub-sea permafrost such as clathrates) contain between 1330 and 1580 Pg (i.e., $\sim 1500 \times 10^{9}$ t) of carbon; it is useful to compare these values with those given in the previous section. Schuur et al. (2011) estimated that thawing permafrost could result in an average annual emission rate of $4-8 \times 10^{9}$ t of $\mathrm{CO}_{2}$ equivalents (considering both $\mathrm{CO}_{2}$ and methane releases) for the period 2011-2040 and annually $10-16 \times 10^{9} \mathrm{t}$ of $\mathrm{CO}_{2}$ equivalents for the period 2011-2100. A useful review of the magnitude of greenhouse gases released due to melting permafrost is provided in the Intergovernmental Panel on Climate Change (IPCC) Special Report on the Ocean and Cryosphere in a Changing Climate (e.g., Meredith et al. 2019).

In addition to processes in the soil, such as the breakdown of organic matter by microrganisms allowing the release of greenhouse gases into the atmosphere, geomorphological processes are influencing the exposure of soil and organic carbon through soil erosion, channel bank erosion, and mass movements, and by influencing the transport and deposition of sediment and associated carbon in aquatic systems (Abbott and Jones 2015; Vonk et al. 2015) (Fig. 6). Thus, Beel et al. (2020) determined that physical disturbance events caused enhanced sediment and particulate organic carbon fluxes in a small $\left(0.21 \mathrm{~km}^{2}\right)$ watershed in the Canadian High Arctic. Monitoring for eight years over the period 2006-2017, the cumulative sediment yield 


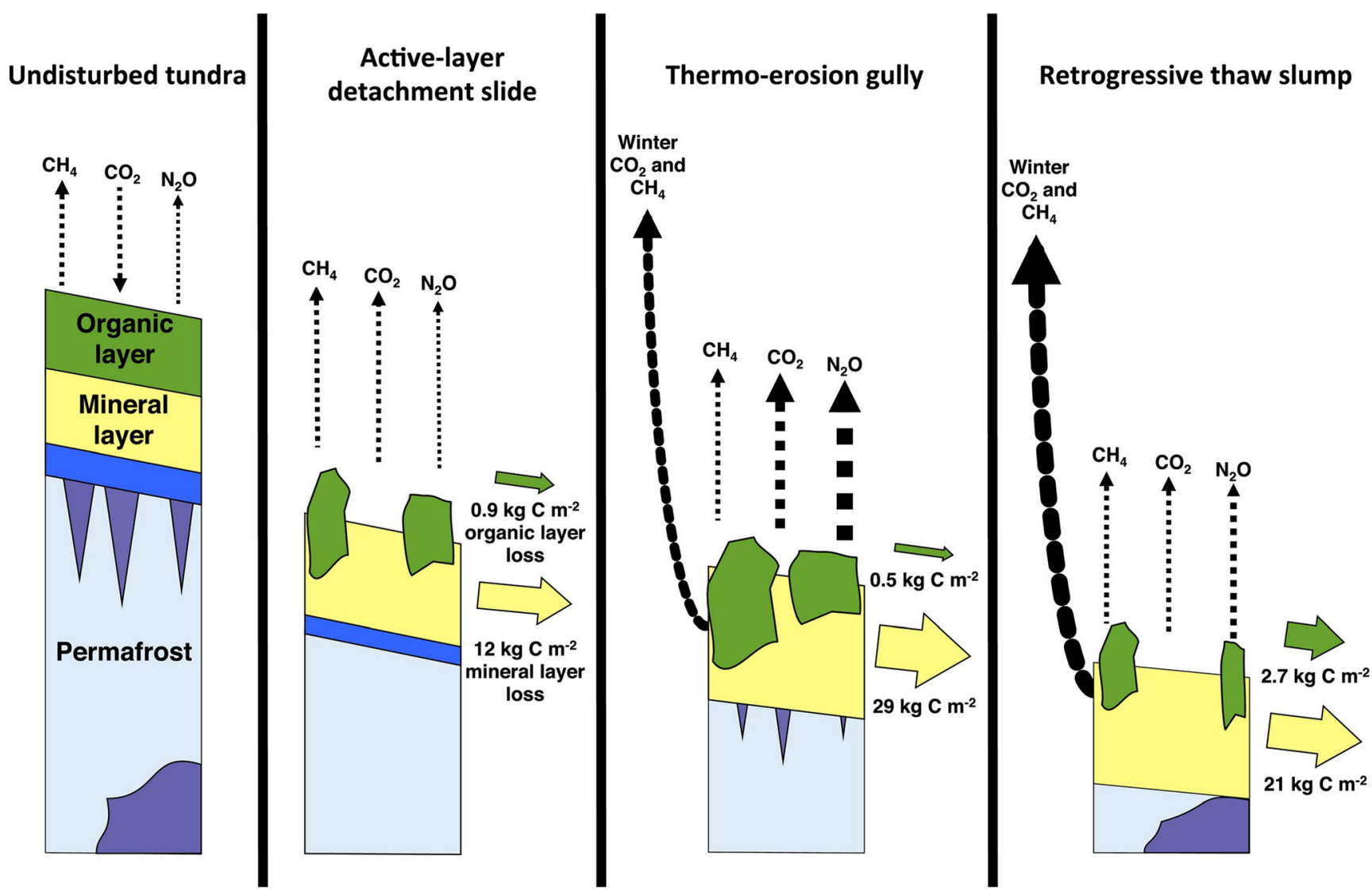

Fig. 6 Conceptual model of the effects of geomorphological processes on carbon (and nitrogen) fluxes in permafrost landscapes, with an emphasis on lateral transport (from Abbott and Jones 2015; reproduced with permission from John Wiley and Sons Ltd)

for a watershed undergoing both physical (e.g., permafrost thaw-related mass movements and erosion) and thermal (e.g., active layer deepening) disturbances was $\sim 300 \mathrm{t} \mathrm{km}^{-2}$, which compares to $\sim 1 \mathrm{t} \mathrm{km}^{-2}$ for an adjacent watershed undergoing just thermal disturbances. In both watersheds, the particulate organic carbon flux was $\sim 1.4 \%$ of the sediment flux.

Such findings have led some (e.g., Plaza et al. 2019; Turetsky et al. 2019, 2020; Vonk et al. 2019) to suggest that hydrological and geomorphological processes are fundamental in predicting the emission of greenhouse gases to the atmosphere and have been largely ignored in existing models. Most models to date assume a slow thaw that is typically from the surface down and that the key processes occur in the surface zone. However, given the documented abundance of mass movement events - especially on steep slopes - and other erosion processes, and the collapse of channel banks, then the degradation of permafrost may be quicker than previously thought. In addition, this degradation will expose deeper soil and sediment profiles, and thus more organic matter, to weathering and transport processes. Vonk et al. (2019, p. 3) suggest that there needs to be a "pivot in Arctic permafrost carbon research.....towards quantifying waterborne pathways of lateral carbon transport."

\subsection{The effects of soil erosion, sediment dynamics, and sediment composition on water security}

While this section addresses issues of water security, it is important to recognize that soil erosion, sediment dynamics, and sediment composition also affect food security. However, to address such impacts at the level of detail required is beyond the scope of the present review. Instead, the reader is directed to key papers and reports (e.g., Brown 1981; Morgan 2005; Pimental 2006; Montgomery 2007a, 2007b; Verheijen et al. 2009; Borrelli et al. 2013; FAO and ITPS 2015; Montanarella et al. 2016; Vanwalleghem et al. 2017; Poesen 2018; FAO 2019a, 2019b).

In 2015, the Member States of the United Nations General Assembly agreed to follow the 2030 Agenda for Sustainable Development (United Nations 2018). The program has 17 sustainable development goals (SDG) of which SDG6 addresses water and sanitation. SDG6 has six main targets, including the following: (i) improve water quality (target 6.3); (ii) increase water use efficiency and ensure freshwater supplies (target 6.4); and (iii) protect and restore water-related ecosystems (target 6.6) (United Nations 2018). The targets within SDG6 align with the broad concept of water security, 
which recognizes the need to protect water (quantity and quality) to meet the needs of human well-being, socio-economic development, and the preservation of ecosystems (United Nations 2013).

From a freshwater perspective, $80 \%$ of the world's population is exposed to high levels of threat to water security (Vörösmarty et al. 2010). Table 3 illustrates the main themes and drivers of stress based on Vörösmarty et al. (2010) (also, see Best (2019) for a review of the stresses on the world's main big rivers). In many cases, the erosion, transport, and deposition of sediment are a direct or indirect stressor. Thus, sediment loading is identified as a direct cause of freshwater "pollution" and linked to this is pollution associated with chemicals that may be attached to sediment such as phosphorus, mercury, pesticides, and organic substances (see Section 3.2.2). Soil erosion of agricultural land (i.e., arable and pasture) influences the amount of land allocated to agriculture - i.e., erosion reduces the productivity of land requiring more land for the same crop yield - thereby creating "watershed disturbance," and in turn contributes to sediment and chemical loading (i.e., "pollution"). Indirectly, sediment fluxes influence the longevity of reservoirs (see Section 3.2.3) and may lead to the construction of more dams

Table 3 The main themes and drivers of stress affecting freshwater security (modified from Vörösmarty et al. 2010). The themes and drivers are listed in relative order of influence with greatest at top

\begin{tabular}{ll}
\hline Theme & Driver \\
\hline Water resources development & Consumptive water loss \\
& Human water stress \\
& Agricultural water stress \\
& Dam density \\
& Flow disruption \\
& River fragmentation \\
Pollution & Organic loading \\
& Pesticide loading \\
& Nitrogen loading \\
& Phosphorus loading \\
& Mercury loading \\
& Sediment loading \\
& Soil salinization \\
& Potential acidification \\
& Thermal alteration \\
& Cropland \\
Impervious surfaces \\
Watershed disturbance & Livestock density \\
& Wetland connectivity \\
& Aquaculture pressure \\
& Fishing pressure \\
& Non-native fishes \\
\hline
\end{tabular}

and reservoirs if lifespans are reduced due to sedimentation (i.e., "water resources development"). Similarly, turbidity in the water column and sedimentation of spawning gravels affects fish species and populations (see Section 3.2.1), which can influence recreational and commercial fishing and lead to the need for aquaculture to meet food requirements (i.e., "biotic factors"). Most of these stressors are also having profound impacts on aquatic biodiversity (Vörösmarty et al. 2010).

Based on the concerns raised by Vörösmarty et al. (2010), the following sections consider in more detail three examples where sediment affect water security. In turn, the examples illustrate how sediment dynamics and composition may influence how the United Nations Member States meet SDG6 targets in terms of aquatic ecosystems (Section 3.2.1), water quality (Section 3.2.2), and freshwater supplies (Section 3.2.3).

\subsubsection{The interaction between sediment and freshwater biota, especially wild salmon}

The impact of fine sediment on freshwater biota has been documented for over 70 years (e.g., Wallen 1951). Research has typically focused on: (i) phytoplankton, periphyton, and macrophytes (e.g., Jones et al. 2012a, 2014; Battin et al. 2016); (ii) zooplankton and benthic invertebrates (e.g., Ryan 1991; Wood and Armitage 1997; Jones et al. 2012b); and (iii) fish (e.g., Newcombe and MacDonald 1991; Kemp et al. 2011; Kjelland et al. 2015). Given the economic value and cultural significance of fish, most research has focused on this group of aquatic organisms, with particular emphasis on salmonids, which includes salmon, trout, chars, freshwater whitefishes, and graylings (Bilotta and Brazier 2008). Research has also addressed the effects of sediment on other fish species including sturgeon (e.g., McAdam et al. 2005) and perch (e.g., Pyle et al. 2005). Figure 7 shows some of the main physical, chemical, and ecological impacts on freshwater biota from excessive sediment inputs due to anthropogenic activities. Work has mainly focused on either the direct impacts of enhanced sediment inputs to freshwater systems (e.g., turbidity and smothering; Kemp et al. 2011) or the effect of chemicals (e.g., nutrients, pollutants) sorbed on the sediment which can cause death or modifications in behavior, among other things (e.g., Pyle et al. 2005). As a consequence, numerous regional and national organizations have developed sediment quality guidelines for the protection of freshwater biota that are often based on sediment concentration (e.g., Bilotta et al. 2012) and/or chemical content (e.g., Persaud et al. 1993; MacDonald et al. 2000) metrics.

Conversely, it is useful to recognize that freshwater biota, such as bacteria and microalgae (e.g., biofilms; Paterson et al. 2018), macrophytes (Petticrew and Kalff 1992; Wharton et al. 2006), and organisms that dig in river and lake substrates (e.g., crayfish, Johnson et al. 2011; salmon, Hassan et al. 2008) can, 


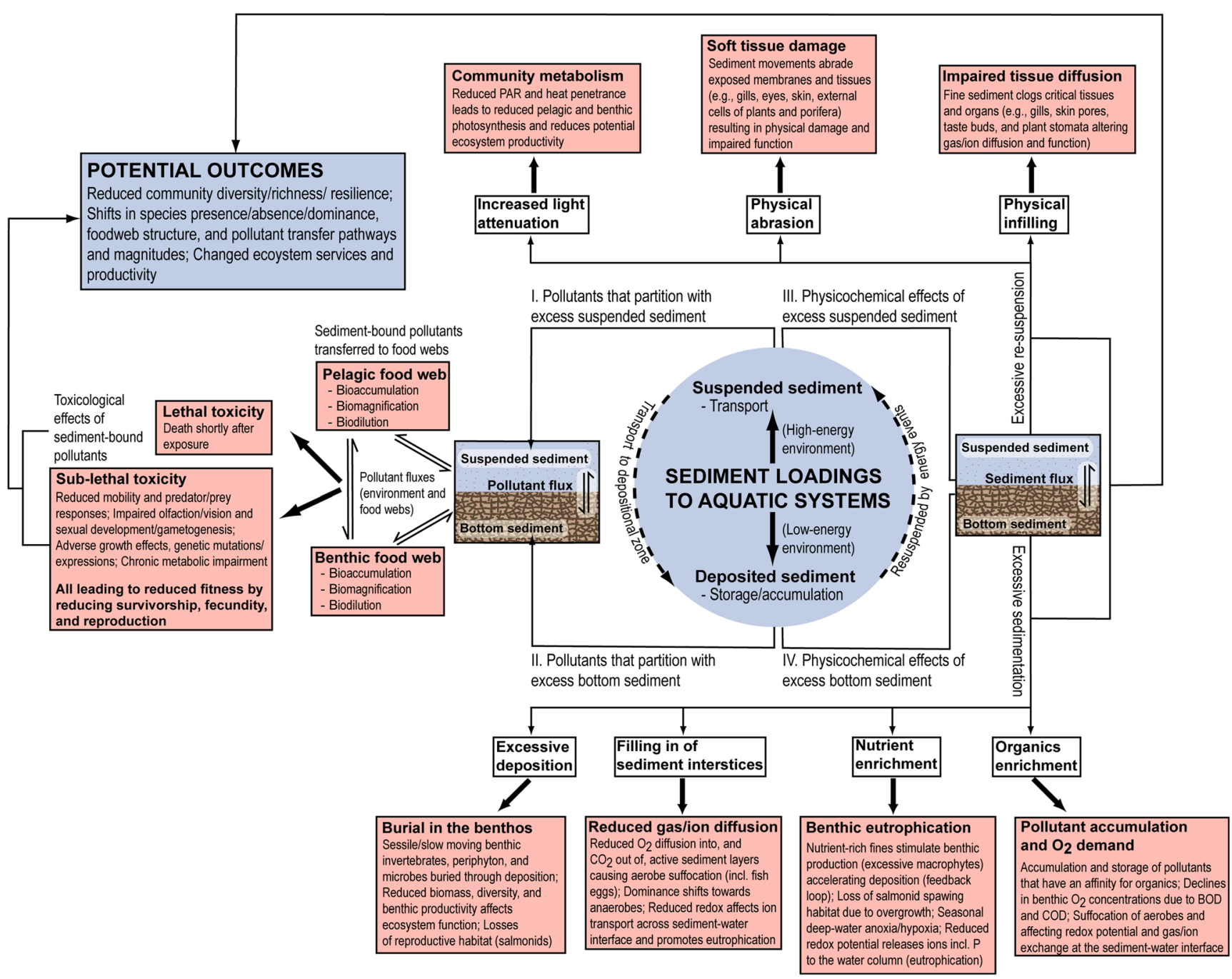

Fig. 7 Some of the main physical, chemical, and ecological impacts on freshwater biota due to excessive fine sediment inputs, usually due to anthropogenic activities (partly based on Wood and Armitage 1997;

in turn, modify sedimentary habitats and can regulate sediment dynamics and fluxes (for a useful review, see Wilkes et al. 2018). This has resulted in terms such as "ecosystem engineers" (Jones et al. 1984).

A useful example, which helps to illustrate the interconnectedness of many of the stressors and impacts on water systems described above (also see Table 3 ) and shows the links between water security and biodiversity in rivers (Vörösmarty et al. 2010), is the history of Pacific salmon (Oncorhynchus sp.) in North America. Most of the rivers of western North America-including the US states of Alaska, California, Idaho, Oregon, and Washington, and British Columbia and Yukon in Canada - had a long history of extensive wild salmon populations which were vital for both marine and freshwater ecosystems (Montgomery 2003). As such, salmon are considered as a cultural and ecological keystone species as their presence affects the socio-economic well-being of local people (Galbreath et al. 2014; Noble et al. 2016) and the
Kemp et al. 2011; Kjelland et al. 2015). BOD, biological oxygen demand; COD, chemical oxygen demand; P, phosphorus; PAR, photosynthetically active radiation

composition, structure, and function of ecosystems (Paine 1966; Hilderbrand et al. 2004), for example as a food source for bears, eagles, orcas, and humans. Furthermore, the role of migrating salmon to spawning streams - often thousands of kilometers from the Pacific Ocean-is essential in the supply of marine-derived nutrients to headwater ecosystems. Thus, stable isotopes of carbon, nitrogen, and sulfur of marine origin have been recorded in stream food webs and riparian vegetation such as trees (e.g., Chaloner et al. 2002; Naiman et al. 2002). More recently, research (e.g., Rex and Petticrew 2008; Albers and Petticrew 2013) has demonstrated the important role of fine-grained sediment in helping to retain organic matter and marine-derived nutrients in headwater streams and lakes, via the formation of larger, composite particles of organic and minerogenic material (i.e., freshwater flocs; cf. Droppo 2001), which is beneficial to these ecosystems.

However, recent decades have seen a dramatic decline in salmon populations, with salmon being absent, or close to this, 
in many rivers in the US states of the Pacific Northwest and declining in British Columbia and Yukon. Numerous explanations have been put forward which reflect the dual freshwater and marine life cycle of these anadromous fish. From a freshwater perspective, changes in river flows, the role of dams, increasing water temperatures (especially temperatures $>20{ }^{\circ} \mathrm{C}$ ), pollution, and sedimentation of river gravels at spawning sites have all been identified (also see Fig. 7). The latter two factors have been linked to increases in sediment delivery from land uses such as agriculture, forestry, mining, and urbanization, in addition to disturbances to river channels (e.g., bank erosion, and gravel and sand mining).

The massive declines in wild salmon populations in the rivers draining into the Pacific Ocean, and in other parts of the world, has focused attention on the role of excessive sediment in spawning grounds, and indeed aquatic ecosystems in general. In turn, this has initiated research programs and policies to control the delivery of sediment to watercourses, including research to identify where the sediment originates from in important salmonid streams (e.g., Walling et al. 2003b; Gateuille et al. 2019; see Section 2.1.4).

\subsubsection{The effect of fluxes of sediment-associated contaminants, including microplastics, on water quality}

One of the greatest threats to water security is pollution (Vörösmarty et al. 2010; Table 3). Given that a large number of pollutants are associated with particles (Horowitz 1991), then soil erosion and sediment transport processes are fundamental in controlling how hydrophobic contaminants behave in drainage basins. In turn, understanding such processes is key for mitigating sediment-associate pollution (see also Section 4.2). There has been a long history of research on the role of soil and sediment particles in moving contaminants from land into watercourses and ultimately the global ocean. Much of the early work focused on metals and trace elements. As explained in Section 2.1.2, several of these elements have been present in the environment for a long time (see Fig. 2). However, most become more widespread and of greater concern following the Industrial Revolution, which started in some parts of the world in the middle of the eighteenth century (for useful reviews, see Förstner and Wittman 1979; Salomons and Förstner 1984; Nriagu and Pacyna 1988; Horowitz 1991; Foster and Charlesworth 1996; Luoma and Rainbow 2008). In the 1950s and 1960s, specific accidents, events, and developments brought attention to other sediment-associated contaminants such as: (i) (methyl)mercury (e.g., Minamata, Japan); (ii) persistent organic pollutants, such as PCBs, PAHs, DDT, organo-pesticides and herbicides; (iii) phosphorus, due to increased application of fertilizers; (iv) fallout radionuclides, due to above-ground atom-bomb tests (e.g., ${ }^{137} \mathrm{Cs}$ ); (v) personal care products (see Section 2.1.2); and (vi) other emerging contaminants such as pathogens (e.g., Carson 1962;
Schindler 1977; Correll 1998; Smil 2000; Rahman et al. 2001; Yunker et al. 2002; Withers and Jarvie 2008; Gateuille et al. 2014; Evrard et al. 2015; Oliver et al. 2005; Droppo et al. 2009; Owens et al. 2019b; Sassi et al. 2020) (Fig. 8). Indeed, as discussed above (Section 2.1), the timing of the release of artificial materials into the environment in large quantities (e.g., fallout radionuclides) may define the start of the Anthropocene Epoch.

In most situations, sediment transport processes result in the movement of associated contaminants over medium to long distances of the order of $10^{1}$ to $10^{3} \mathrm{~km}$ in watersheds and longer once in the global ocean. As explained in Section 3.1.1, if particles become suspended into the air column (e.g., wind erosion of bare land or unconsolidated deposits), they can move of the order of $10^{1}$ to $10^{4} \mathrm{~km}$ associated with atmospheric circulation patterns; the circumference of the Earth is about $40,000 \mathrm{~km}$. Generally, transport of sediment by water and wind erosion processes over medium to long distances tends to dilute associated contaminant concentrations and activities (as in the case of fallout radionuclide activities), due to mixing with uncontaminated sediment. However, of particular concern is where contaminated sediment becomes focused; i.e., areas of deposition. In some cases, such as floodplains, lakes, and reservoirs, the deposited contaminated sediment may be an immediate threat to ecosystems and human health. In other situations, the contaminated sediment may be buried by cleaner material, either naturally or as part of a management strategy (i.e., capping), and remains a long-term threat to ecosystems and humans if the contaminants have long chemical, biological, or radioactive half-lives.

Microplastics in the environment represent a particularly hot topic of research in recent years. Plastics have likely been in the environment since the early twentieth century, with polyvinyl chloride (PVC) developed in the 1870s and commercialized in the 1920s, and polyethylene and polypropylene commercialized in the 1930 s and 1950 s, respectively (Andrady and Neal 2009). Thus, while not an "emerging contaminant," microplastics have attracted much interest over the last 5-10 years. Most interest is in the global oceans. Eriksen et al. (2014) estimate that there are 5 trillion pieces of microplastics $(<5 \mathrm{~mm})$, with a mass of $250,000 \mathrm{t}$, in the global ocean. Furthermore, microplastics have been recorded in remote parts of the world, including the Arctic and high mountain environments (e.g., Allen et al. 2019; Ambrosini et al. 2019; Bergmann et al. 2019), suggesting that this is now a global issue. While much research has been conducted in marine environments, recent research has highlighted the important role of fluvial sediment as a vector for microplastics (Windsor et al. 2019). Some studies (e.g., Lebreton et al. 2017; Schmidt et al. 2017) estimate that the annual delivery of micro- and macroplastics to the global ocean from rivers is in the range 0.4 to $4.0 \times 10^{6} \mathrm{t}$. 


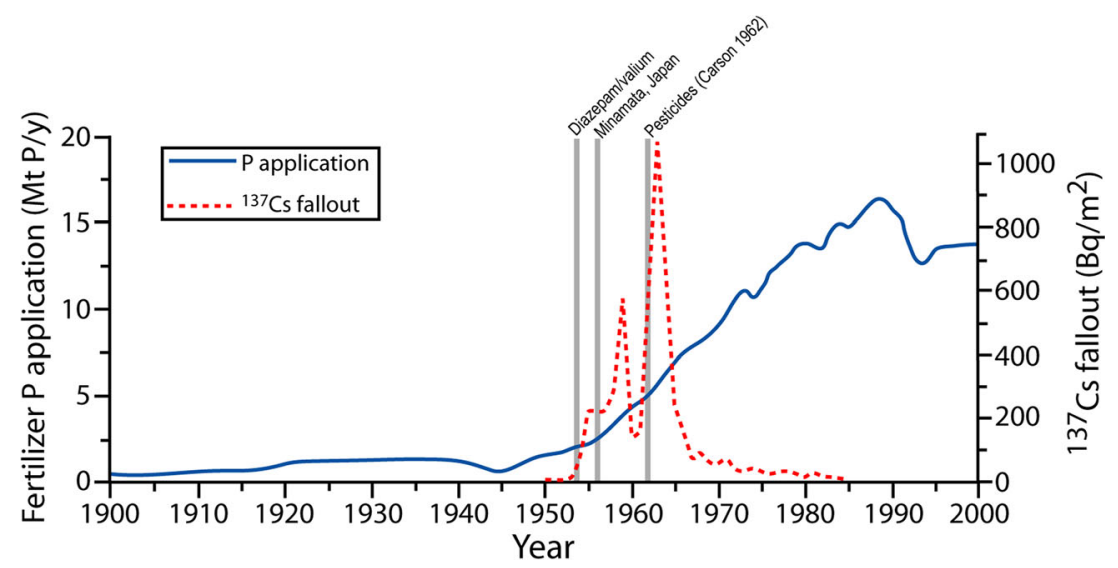

Fig. 8 Temporal evolution of fertilizer-based phosphorus (P) application to land and bomb-derived cesium-137 $\left({ }^{137} \mathrm{Cs}\right)$ fallout to the Earth's surface over the period 1900 to 2000 (modified from Smil 2000; Evrard et al. 2020). Also shown are some key events that occurred in the 1950s and 1960 s, such as the introduction of pharmaceutical products (e.g., diazepam/valium in 1953) in France (see Thiebault et al. 2017), the

A review by Hurley et al. (2018) shows that sedimentary environments in rivers, such as channel beds, often contain among the highest concentrations of microplastics recorded to date, often greater than concentrations in surface waters. The maximum recorded concentration was $>500,000$ particles $\mathrm{m}^{-2}$ (depth of channel bed sampled was $\sim 10 \mathrm{~cm}$ ) for the River Tame in the UK. Rivers in Canada, Germany, and the UK often exceeded average and maximum values of 1000 and 10,000 particles $\mathrm{m}^{-2}$ (100 and 1000 particles $\mathrm{kg}^{-1}$, respectively). Sediment in lake, estuarine, and beach environments also had high contents of microplastics (Hurley et al. 2018). Thus, from an ecosystem perspective, the storage of microplastics in sedimentary deposits could represent a threat to aquatic organisms, including benthic invertebrates and salmonids. Hurley et al. (2018) not only determined the high number of microplastics stored in channel bed sediment in urbanized rivers in the UK but also demonstrated the important role of high-magnitude floods in scouring the upper layers of channel bed sediment. As such, channel beds transitioned from a net sink to a net source of microplastics to the water column during high-flow events. This represents an important mechanism for delivering microplastics to coastal zones and the global ocean. It also presents a risk to human health and suggests that there may be high levels of microplastics in surface drinking water supplies during high-flow events in drainage basins where there are industrial (e.g., manufacturing) and urban activities (i.e., high population densities, wastewater treatment plants, and combined sewer overflows) that produce microplastics (Fig. 9). From a mitigation perspective, if channel bed sediment and other sedimentary environments like floodplains and urban wetlands represent an area where microplastics may concentrate, there may be an opportunity to remove microplastics from aquatic environments by, for example, dredging or scraping. However, while the solution may appear to be a simple one, the costs-both economic and discovery in 1956 of the widespread release of methylmercury into Minamata Bay, Japan, which caused numerous deaths, and the publication of Carson (1962) which reported the problems associated with synthetic pesticides (e.g., dichloro-diphenyl-trichloroethane, DDT) which were introduced into the environment in the 1940s and 1950s

social - associated with such actions may make it unrealistic. As with other sediment-associated contaminants (Section 2.1.2), sediment archives may play an important role in understanding the pollution of aquatic systems with microplastics (e.g., Turner et al. 2019), and the success of mitigation measures.

\subsubsection{Sedimentation in reservoirs and river channels and impacts on water availability}

Dams and associated reservoirs represent one of the greatest disturbances to the functioning of river systems by fragmenting drainage basins, reducing connectivity, and modifying water flows (Walling 2006; Vörösmarty et al. 2010; Best 2019; see Table 3). Grill et al. (2019) estimate that $37 \%$ of the world's long rivers (i.e., $>1000 \mathrm{~km}$ in length) are free-flowing over their entire length, and only $23 \%$ flow uninterrupted to the global ocean. Not only do reservoirs limit the movement of aquatic organisms, such as salmon (see Section 3.2.1), but they also alter the hydrology and geomorphology of downstream watercourses. They also influence the delivery of sediment and nutrients to downstream coastal zones, modifying deltas, and in some cases threatening communities due to the combined effects of a deficit in sediment supply (i.e., sinking) and rising sea levels. For example, Kondolf et al. (2019) have shown how changes to the sediment budget of the Mekong River drainage basin, in part brought about by the construction of dams, have affected the Mekong delta, threatening the livelihoods of its 17 million inhabitants. Recently, however, the importance of the role of dams on the size and functioning of coastal deltas has been questioned (Ibáñez et al. 2019), and globally, the total area of deltas has increased as losses due to dams have been offset by net increases in sediment supply due to deforestation and other land use activities (Nienhuis et al. 2020). 


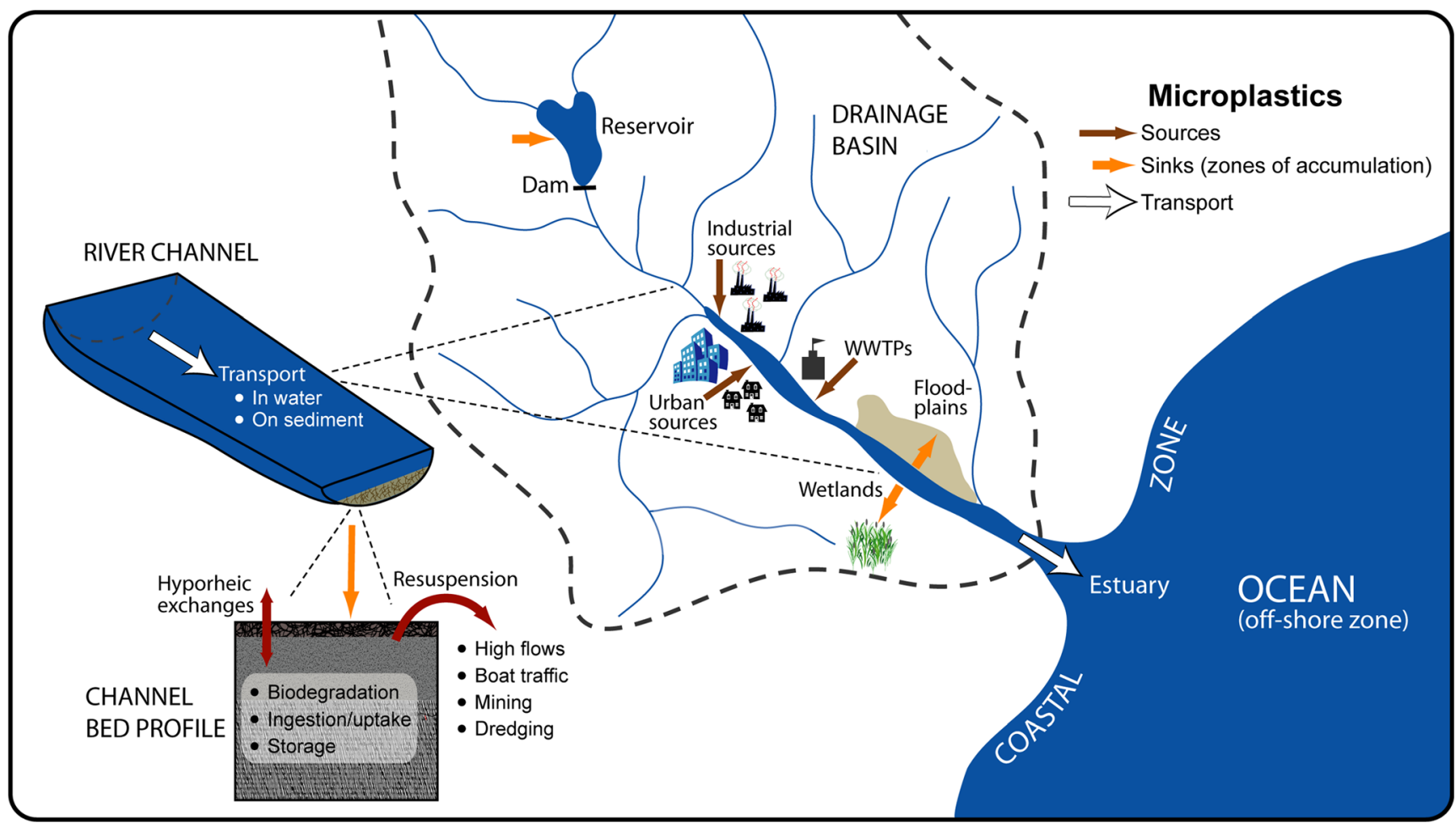

Fig. 9 Schematic representation of sources, pathways, and sinks of microplastics in a drainage basin with an emphasis on processes in the river channel; WWTPs, wastewater treatment plants

In terms of water security, many reservoirs are constructed as a source of drinking water. Sedimentation of reservoirs reduces their lifespan. As a consequence, Morris (2020, p. 2) argues that "declining reservoir capacity directly threatens our ability to provide reliable water supplies for agriculture and urban use." Spain and the USA have long histories of reservoir construction and thus provide useful examples of the impact of sedimentation on reservoir capacity. Spain has the most reservoirs of any country in Europe and about $2-3 \%$ of the world's total. In the Ebro River drainage basin, Spain, Batalla (2003) estimated that the annual reduction in reservoir capacity due to sedimentation was $\sim 0.2 \%$, giving an estimated sedimentation rate of $15 \times 10^{6} \mathrm{~m}^{3}$ year ${ }^{-1}$. The cumulative effect of all of the reservoirs in the Ebro drainage basin is that the sediment load discharged to the Mediterranean Sea $\left(\sim 200,000\right.$ t year $\left.^{-1}\right)$ is only about $1.5 \%$ of what was delivered at the beginning of the twentieth century. At the national scale, Avendaño et al. (1997) estimate that $\sim 10 \%$ of reservoirs in Spain have experienced a reduction in capacity of $50 \%$ or more. In California, USA, sedimentation in reservoirs has caused a reduction in capacity estimated at $\$ 6$ billion in replacement costs each year (Fan and Springer 1993). In the USA as a whole, per capita reservoir storage capacity peaked in 1975 at $45,000 \mathrm{~m}^{3}$ person $^{-1}$ but in 2019 this had declined to $27,000 \mathrm{~m}^{3}$ person ${ }^{-1}$ (Randle et al. 2019; Morris 2020).

Despite the widespread recognition of the problems that dams and reservoirs create in drainage basins and coastal zones, and specifically on water supply issues due to sedimentation, it is possible to limit these issues through a combination of watershed management and reservoir engineering (Kondolf et al. 2014). Morris (2020) identifies four types of sediment management strategy: (i) reduce the sediment delivered from the contributing watershed; (ii) route sediment-laden water around or through the storage pools; (iii) remove sediment following deposition (e.g., dredging); and (iv) have adaptive strategies which respond to the loss in capacity, without addressing the sediment imbalance (Fig. $10)$.

Sediment transport and sedimentation in river channels also have impacts on water security by influencing the provision of reliable freshwater supplies and affecting water quality through elevated turbidity and contaminants. In recent decades there has also been increasing concern associated with flooding due to a combination of climate changes (e.g., increases in amount and intensity of rainfall) and human activities (e.g., degradation of soil structure and increases in impervious surfaces). In many cases, the situation is made worse by river engineering activities for hydropower, navigation, and (ironically) flood control, which have influenced river discharge and the conveyance of both suspended sediment and bedload (e.g., Habersack et al. 2016; Liu et al. 2018). In the European Union, for example, there have been policy developments to address these concerns, such as the Water Framework Directive (WFD; EC 2000) and Floods Directive (FD; EC 2007). 


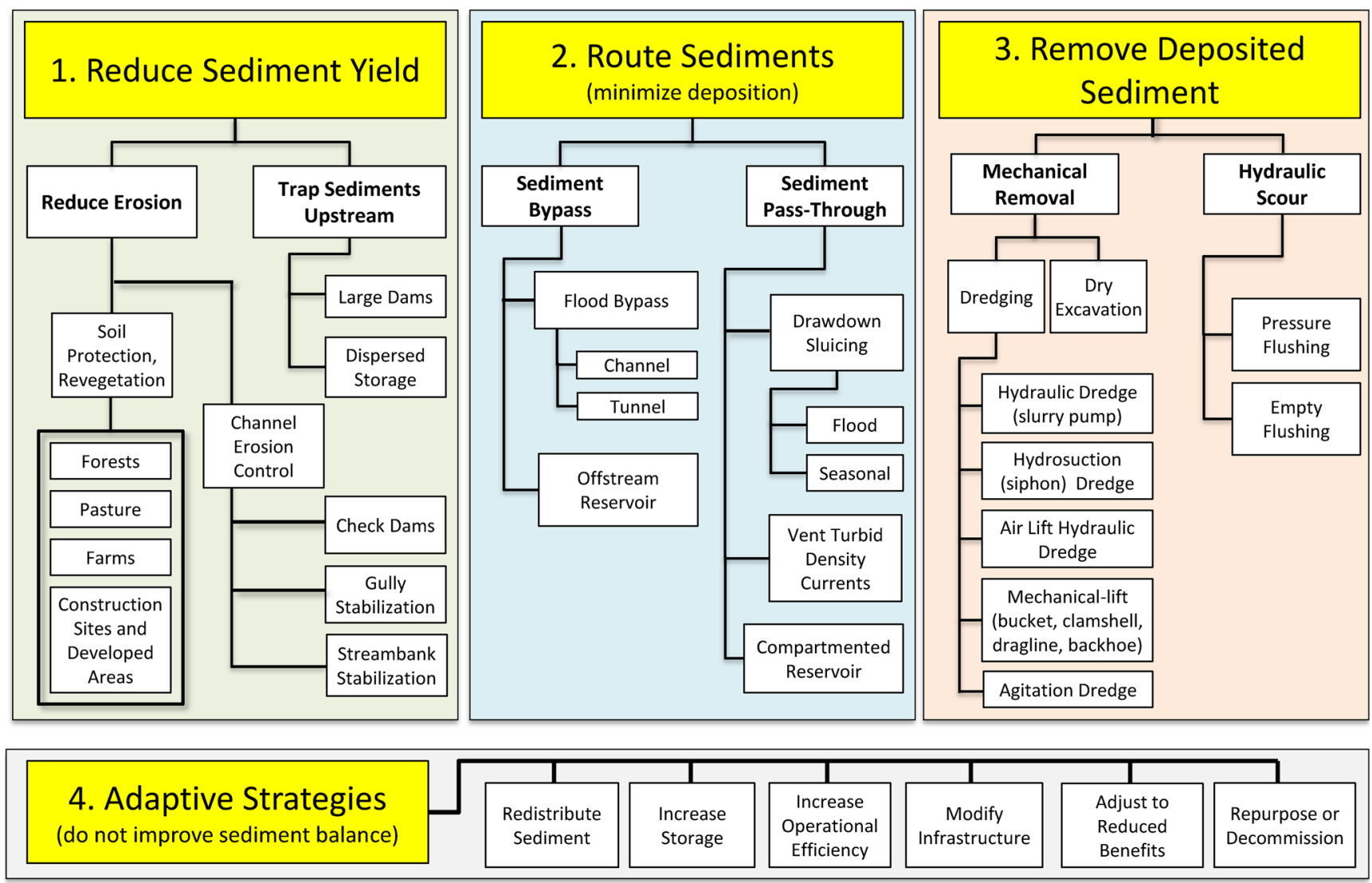

Fig. 10 Classification of strategies for managing reservoir sedimentation (from Morris 2020; reproduced with the permission of MDPI)

These directives require member states to develop river basin management plans to achieve good chemical and ecological water status (WFD) and to assess and manage flood risks so as to mitigate the negative effects of flooding (FD). Despite the obvious importance of sediment delivery, transport, and sedimentation on water quality, aquatic ecosystems, and flood risk, many have argued (e.g., Förstner 2002; Förstner and Owens 2007; Brils 2008, 2020; Collins and Anthony 2008) that European Union countries might fail to meet the required targets identified in these directives due to a lack of understanding of the importance of sediment dynamics and composition. In the case of the Floods Directive, specifically, this in part stems from a limited appreciation of the role of in-channel and floodplain sedimentation on river hydromorphology (Nones et al. 2017; Nones 2019) and the need for rivers to maintain channel capacity, often by being allowed to migrate in an unrestricted way across their floodplains (e.g., Lane et al. 2007). This disconnect between scientific understanding and policy development has led some to advocate for a greater appreciation of the importance of sediment budgets and sediment routing models as management tools (e.g., Slaymaker 2003; Owens 2005; Walling and Collins 2008), including within river basin management plans (Nones 2019; Brils 2020).

\section{The use of sediment to assess the effectiveness of management and mitigation practices}

Most of the examples above have been used to describe the timing and magnitude of the negative impact of humans on environmental systems, specifically in terms of soil erosion, sediment dynamics, and sediment composition, over a range of times scales including historic (Section 2.1), recent (Section 3), and future (Section 2.2). As mentioned earlier, this leads to the perception of sediment as a problem, while failing to recognize the important functions of sediment in aquatic systems (Owens et al. 2005; Bilotta and Brazier 2008; Owens 2008). Not only do sediment represent an important aquatic ecosystem for organisms like invertebrates and for spawning fish like salmon and sturgeon, but they are also vital for the fluxes of essential biogeochemical elements. Furthermore, sediment dynamics help to regulate the morphology of a range of aquatic features such as river channels, floodplains, lakes, wetlands, estuaries, and deltas. In this context, excessive reductions in sediment delivery and transport can be just as detrimental as excessive increases (e.g., "hungry waters," Kondolf 1997). With this in mind, it seems appropriate to consider how sediment can be used to assess if management and mitigation measures can be used to return 
environmental systems back to more "normal" conditions. Here, the term "normal" is not necessarily meant to imply pre-human - or even pre-Anthropocene - conditions, as this is either unrealistic or not cost-effective. In other words, while technological and socio-economic solutions might exist, the environmental benefit of trying to achieve perfect environmental conditions may not warrant the unreasonably high cost required. In such situations, cost-benefit (or costeffectiveness) analysis is a useful tool (Slob et al. 2008; Rickson 2014; Benisiewicz et al. 2020). The examples below help to illustrate how information on sediment fluxes and quality can be used as an indicator to assess if management and mitigation measures are being effective in reducing wider environmental degradation. For example, reductions in excessive soil erosion and sediment delivery to watercourses are good indicators of improvements in soil and water functions and probably overall ecosystem health.

\subsection{Effects of mitigation measures on soil erosion and sediment fluxes in China}

China has a dense network of gauging stations that extend back many decades, including stations implemented by the Yellow River Conservancy Committee in the 1950s. Consequently, numerous studies have been able to evaluate the effect of recent conservation measures on erosion and sediment fluxes in the Loess Plateau and elsewhere (e.g., Fang 2019; Hu et al. 2019; Wu et al. 2020). In most cases, rates of soil erosion and sediment fluxes in rivers have decreased dramatically often due to the implementation of conservation measures like landscape engineering, river terracing, check dams and reservoir construction during the period 1960s to 1990s, and more recently from the Three Gorges Reservoir and programs aimed at restoring the "natural" vegetation cover (Wang et al. 2016; Wu et al. 2020). For example, Zhao et al. (2019) analyzed runoff and sediment transport records for four catchments in the Loess Plateau region for the period 1960-2016 and showed a significant decrease in river discharge and sediment loads, especially after 2000 , which they attributed to the Green for Grain program that was implemented in 1999. This program encouraged, via subsidies and other compensatory measures, farmers to convert steep farmland that was susceptible to erosion back to grassland and forest. By most accounts, the program has been successful and by 2010 about 15 million hectares of farmland and 17 million hectares of barren, mountainous wasteland were converted back to "natural" vegetation cover. This has involved > 120 million people, mainly farmers and land owners (Delang and Yuan 2015). In many respects, the Green for Grain program may be the largest national program to reduce soil erosion and sediment transport to date, and sediment monitoring stations have been central to both its creation (by identifying the need) and its evaluation.

\subsection{The role of mitigation in reducing sediment- associated contaminant fluxes}

As described in Section 2.1.2, sediment archives such as those found on floodplains and in lakes, reservoirs, and estuaries can be used to reconstruct environmental changes over time scales ranging from decades to thousands of years. As such, they can be used to inform management and decision-making by identifying the amount of remediation required (e.g., Foster et al. 2011; Fig. 11) or to assess the response of watersheds to mitigation measures. For example, Owens and Walling (2003) used floodplain cores to show how the content of several metals, including chromium, copper, and lead decreased in the urbanized River Aire catchment, UK. Thus, chromium decreased from peak values of $\sim 300 \mathrm{\mu g} \mathrm{g}^{-1}$ in the early twentieth century to $\sim 100 \mu \mathrm{g} \mathrm{g}^{-1}$ at the turn of the twenty-first century (Fig. 12a); the probable effect level (PEL) sediment quality guideline for chromium is $90 \mu \mathrm{g} \mathrm{g}^{-1}$ (Miller and Orbock Miller 2007). The decline reflected a change in the type of industry found in the catchment and the introduction and improvement of sewage treatments works. Similarly, Fig. $12 \mathrm{~b}$ shows the effect of mercury mining on mercury levels recorded in a sediment core collected from Stuart Lake in British Columbia. Mining was operational between 1940 and 1944 and then again between 1968 and 1975. In the earlier period, mercury levels reached $>150 \mathrm{ng} \mathrm{g}^{-1}$, as mine tailings were dumped directly into a connected lake (Pinchi Lake), whereas in the recent period levels were $<30 \mathrm{ng} \mathrm{g}^{-1}$ due to a series of stricter environmental regulations, and levels were essentially the same as those prior to mining (Lockhart et al. 2000; Gallagher et al. 2004). Although the mercury contents of sediment in Stuart Lake were below Canadian PEL values (500 ng g ${ }^{-1}$ ), values for sediment collected from Pinchi Lake were $>5000 \mathrm{ng} \mathrm{g}^{-1}$ in places (Weech et al. 2004).

Sometimes, the changes in trace element concentrations exhibit a complex pattern showing both changes in industrial activity and environmental policies. Figure 12c shows downcore concentrations in copper for a core collected from the estuary of the Grande-de-Xubia River in Spain. Values increased from the end of the nineteenth century reflecting the start of industrialization, which accelerated after the Spanish Civil War (1936-1939) and especially World War II (1939-1945). Between 1973 and 2000, concentrations declined due to industrial collapse in the region following an international recession, and social and political instability in Spain. After 2000, industrial activity in the region increased, due to a second industrial transition, but this did not result in a noticeable increase in copper concentrations due to more stringent environmental protection policies and regulations, including the European Water Framework Directive (ÁlvarezVázquez et al. 2020).

However, while such environmental policies and regulations have tended to markedly reduce the levels of metals 
Fig. 11 The concept of using paleolimnological reconstruction of sediment and contaminant dynamics within aquatic systems to inform management and decision-making (modified from Foster et al. 2011)
Time of

disturbance/change

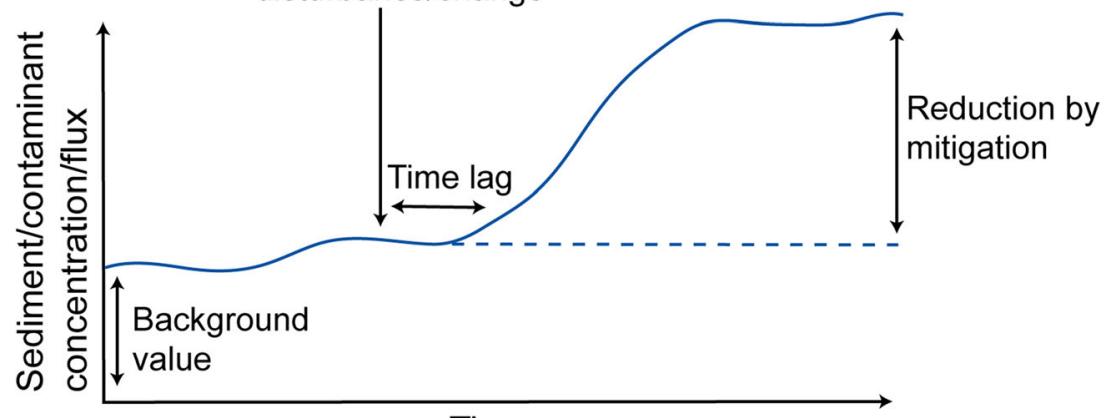

Time

and other contaminants recorded in sediment deposits downstream of urban and industrial areas, extreme accidents, such as catastrophic mine tailings failures and accidents at nuclear plants, can still result in massive contamination of aquatic systems (e.g., Evrard et al. 2013; Kossoff et al. 2014; Queiroz et al. 2018; Hatam et al. 2019; Meusburger et al. 2020).

\section{Perspective}

The previous sections have illustrated how information on soil erosion, sediment dynamics, and sediment composition have been central to our understanding of the natural evolution of the Earth and especially the role of humanity in modifying environmental systems, often in a detrimental way, such that we now consider ourselves in a new geological epoch, the Anthropocene. In particular, terrestrial and marine sediment archives have proven to be particularly useful in that they can contain information that is not readily available from other sources, with the exception of long ice cores and geological strata. Importantly, sediment archives enable us to assemble information over a variety of timescales (i.e., $10^{0}$ to $10^{5}$ years and longer) and a range of spatial scales from sub-watershed to continental, in addition to environments ranging from arid to tropical to polar. As such, sedimentary records have enabled us to determine how environmental conditions and processes respond to change and have been able to capture the full variability associated with such responses, which is often lacking in short-to-medium term monitoring programs. This information, coupled with detailed experiments and studies on processes (including measurement and monitoring), has provided the basis on which most large-scale models have been developed, including global circulation models and global earth system models. These models have enabled us to forecast what might lie ahead and provide a means to decide on the best path forward.

But our large-scale and global models are not perfect, in part because they are not yet able to fully capture the complexities of Earth system processes including feedback processes. Thus, there is a need for additional studies that are concerned with understanding environmental processes and
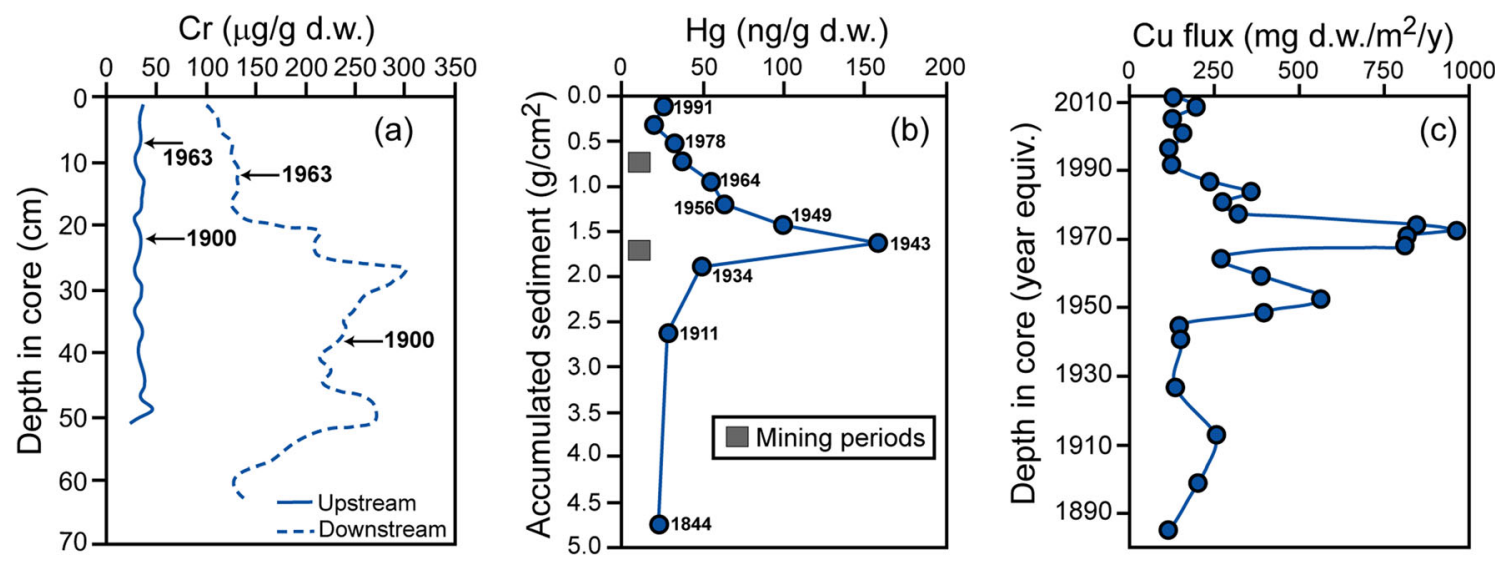

Fig. 12 Examples to illustrate how sedimentary archives can be used to document decreasing contamination due to improved environmental management and policies. a Downcore changes in the chromium $(\mathrm{Cr})$ content of sediment in a floodplain core collected from the River Aire, UK, upstream and downstream of the city of Leeds (modified from Owens and Walling 2003). b Mercury (Hg) content of sediment in a core

collected from Stuart Lake, British Columbia, Canada, during two different phases of mining activity in the watershed (modified from Lockhart et al. 2000). c Temporal changes in the flux of copper $(\mathrm{Cu})$ based on a sediment core collected from the estuary of the Grande-de-Xubia River, Spain (modified from Álvarez-Vázquez et al. 2020). Core chronologies were established using ${ }^{137} \mathrm{Cs}$ and unsupported ${ }^{210} \mathrm{~Pb}$ dating 
reconstructing how environments respond to changes brought about by human activities. As a conclusion to this review, some examples of future research needs are described below; however, this is by no means an exhaustive list.

\subsection{Testing for uniformitarianism}

Much of our forecasting using models is based on the assumption that what happened in the past, and present, can be extended into the future. Indeed, it is difficult to envisage an alternative way of viewing how complex environmental systems operate. But it does raise some important questions. (i) What if we are not realistically representing all of the relevant processes? For example, we typically only consider one erosion process in isolation, failing to recognize the synergistic interaction between water, wind, tillage, and other processes in eroding soils (e.g., Li et al. 2007; Poesen 2018). (ii) What if the relation between two variables changes? For example, there is plenty of evidence to show that sediment yields from watersheds are related to upstream erosion rates. Consequently, it is generally believed that soil conservation practices will reduce sediment delivery to rivers and thus downstream sediment yields. However, studies have shown that reduced soil erosion is not always matched by reduced sediment yields if other processes buffer the system (e.g.,
Trimble 1983). As such, we need to understand better if the assumptions upon which models are based are valid, and if soil and sediment processes are being realistically represented in these models.

\subsection{Hot spots and hot moments}

We are increasingly realizing that while many key processes operate continuously, there are times and places which disproportionately affect the functioning of environmental systems; the so-called hot spots and hot moments (McClain et al. 2003). Intrinsically linked to this is the concept of temporal and spatial connectivity (see Section 2.2). For example, riparian zones are an important part of landscapes connecting hillslopes to aquatic systems and thus helping to regulate water and biogeochemical fluxes between the two. In most situations, these and similar zones are most active during hydrological events (e.g., rainfall and snowmelt events) and at certain locations (e.g., flow pathways) (Vercruysse et al. 2017). Indeed, these events and locations may represent $<10 \%$, and possibly $<1 \%$, of the total. For example, Walling et al. (1992) determined that $\sim 90 \%$ of the suspended sediment load of the River Exe, UK, over a 2-year period was transported in $\sim 5 \%$ of the time. As such, more research and management efforts should be concentrated on these key aspects.

\section{Transformative research to address global environmental issues}
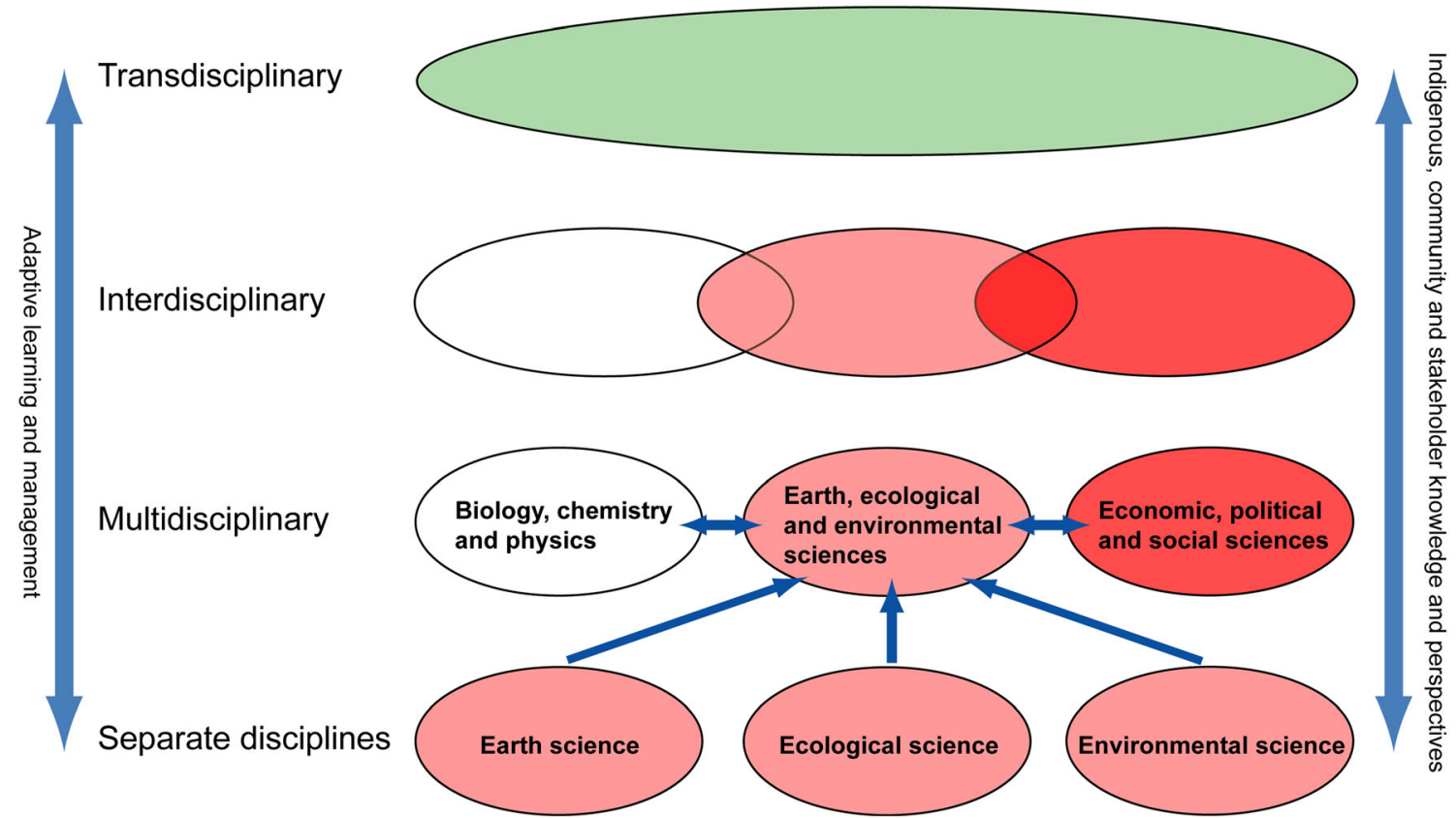

Fig. 13 Approaches to learning with an emphasis on the need for transdisciplinary approaches which integrate knowledge from numerous academic disciplines in order to solve the main global environmental problems. In order to be truly transformative this must: (i) be integrated with Indigenous, local, and stakeholder knowledge and perspectives; (ii) deliver to policy frameworks; and (iii) be adaptive in nature 


\subsection{Understanding cumulative effects in the wider context of Earth systems}

Because of the inherent difficulties associated with environmental research, most projects tend to focus on one or more aspects, such as the response to land conservation measures or a wildfire or increases in precipitation. In reality, watersheds respond to many stressors and drivers, acting simultaneously but not necessarily synchronously. Few studies have attempted to investigate cumulative effects on sediment dynamics in large watersheds (e.g., Smith and Owens 2014; Gateuille et al. 2019) and placed such work within the wider context of Earth systems. In order to address this, research involving coordinated multi- and interdisciplinary teams is required (e.g., earth, ecological and environmental sciences; Fig. 13.). The critical zone concept (e.g., Anderson et al. 2007; Brantley et al. 2007; Derry and Chadwick 2007), and the implementation of critical zone observatories in the USA, is a good example of the benefits of interdisciplinary research.

\subsection{Understanding human behavior and the need for transformative research programs}

Our understanding of biophysical disturbance-response systems needs to be linked to socio-economic behavior and political frameworks. This is particularly important because often, human behavior is not rational given our known understanding of environmental degradation, and humanity has often been slow to respond to known global environmental problems (e.g., Carson 1962; Hansen et al. 1981; Diamond 2005; Montgomery 2007a; Mitchell 2009). Ultimately, the research community needs to do a better job of translating knowledge of Earth system behavior into policy development and actions. This may necessitate moving to transdisciplinary thinking - including the incorporation of Indigenous, local, and stakeholder knowledge and perspectives (e.g., Wilkinson et al. 2020) - and developing transformative research programs (Fig. 13). It will also require adaptive learning and management frameworks (e.g., Holling 1978; Walters 1986; Owens 2009; Williams 2011) that allow for flexibility in response to knowledge development.

Acknowledgments The author would like to acknowledge that some of the ideas presented in this paper have developed in discussion and collaboration with several scientists including Will Blake, Caroline Clason, Alex Koiter, David Lobb, Ellen Petticrew, and Jamie Woodward. Thanks are extended to David Gateuille for help with Figure 4. A special thanks goes to Todd French for assistance in preparing most of the diagrams. The valuable comments from two referees greatly improved the focus and clarity of the paper.

\section{Compliance with ethical standards}

Conflict of interest The author declares that they have no conflict of interest.
Research involving human participants and/or animals None.

Informed consent N/a.

Open Access This article is licensed under a Creative Commons Attribution 4.0 International License, which permits use, sharing, adaptation, distribution and reproduction in any medium or format, as long as you give appropriate credit to the original author(s) and the source, provide a link to the Creative Commons licence, and indicate if changes were made. The images or other third party material in this article are included in the article's Creative Commons licence, unless indicated otherwise in a credit line to the material. If material is not included in the article's Creative Commons licence and your intended use is not permitted by statutory regulation or exceeds the permitted use, you will need to obtain permission directly from the copyright holder. To view a copy of this licence, visit http://creativecommons.org/licenses/by/4.0/.

\section{References}

Abbott BW, Jones JB (2015) Permafrost collapse alters soil organic carbon stock, respiration, $\mathrm{CH}_{4}$ and $\mathrm{N}_{2} \mathrm{O}$ in upland tundra. Glob Chang Biol 21:4570-4587

Albers SJ, Petticrew EL (2013) Biogeomorphic impacts of migrating salmon and disturbance: implications of salmon spawning and decay. Geomorphology 202:43-50

Allen S, Allen D, Phoenix VR, Le Roux G, Jiminez PD, Simonneau A, Binet S, Galop D (2019) Atmospheric transport and deposition of microplastics in a remote mountain catchment. Nat Geosci 12:339-344

Álvarez-Vázquez MÁ, Álvarez-Oglesias P, De Uña-Álvarez E, Quintana R, Caetano M, Prego R (2020) Industrial supply of trace elements during the "Anthropocene": a record in estuarine sediments from the Ria of Ferrol (NW Iberian Peninsula). Mar Chem 223:103825

Ambrosini R, Azzoni RS, Pittino F, Diolaiuti G, Franzetti A, Parolini M (2019) First evidence of microplastic contamination in the supraglacial debris of an alpine glacier. Environ Pollut 253:297-301

Anderson SP, von Blanckenburg F, White AF (2007) Physical and chemical controls on the critical zone. Elements 3:315-319

Andrady AL, Neal MA (2009) Applications and societal benefits of plastics. Phil Trans R Soc B 364:1977-1984

Arnold JG, Srinivarsan R, Muttiah RS, Williams JR (1998) Large area hydrologic modelling and assessment. Part I: model development. J Am Water Resour Assoc 34:73-89

Asselman NEW, Middelkoop H, van Dijk PM (2003) The impact of changes in climate and land use on soil erosion, transport and deposition of sediments in the River Rhine. Hydrol Process 17:3225-3244

Avendaño C, Cobo, Sanz ME, Gómez JL (1997) Capacity situation in Spanish reservoirs. I.C.O.L.D. $19^{\text {th }}$ Congress on Large Dams, 74 , R.52, pp. 849-862

Baartman JEM, Nunes JP, Masselink R, Darboux F, Bielders C, Degre A, Cantreul V, Cerdan O, Grangeon T, Fiener P, Wilken F, Schindewolf M, Wainwright J (2020) What do models tell us about water and sediment connectivity? Geomorphology 367:107300

Bartley R, Bainbridge ZT, Lewis SE, Kroon FJ, Wilkinson SN, Brodie JE, Silburn DM (2014) Relating sediment impacts on coral reefs to watershed sources, processes and management: a review. Sci Total Environ 468-469:1138-1153

Batalla RJ (2003) Sediment deficit in rivers caused by dams and instream gravel mining. A review with examples from NE Spain. Cuaternario y Geomorfoloía 17:79-91

Batista PVG, Davies J, Silva MLN, Quinton JN (2019) On the evaluation of soil erosion models: are we doing enough? Earth Sci Rev 197: 102898 
Battin TJ, Kaplan LA, Findlay S, Hopkinson CS, Marti E, Packmann AI, Newbold JD, Sabater F (2008) Biophysical controls on organic carbon fluxes in fluvial networks. Nat Geosci 1:95-100

Battin TJ, Besemer K, Bengtsson MM, Romani AM, Packmann AI (2016) The ecology and biogeochemistry of stream biofilms. Nat Rev Micriobiol 14:251-263

Beel CR, Lamoureux SF, Orwin JF, Pope MA, Lafrenière MJ, Scott NA (2020) Differential impact of thermal and physical permafrost disturbances on High Arctic dissolved and particulate fluvial fluxes. Sci Rep 10:11836. https://doi.org/10.1038/s41598-20-68824-3

Benisiewicz B, Momblanch A, Leggatt A, Holm IP (2020) Erosion and sediment transport modelling to inform payment for ecosystem services. Environ Model Assess. https://doi.org/10.1007/s10666-02009723-9

Bergmann M, Mutzel S, Primpke S, Tekman MB, Trachsel J, Gerdts G (2019) White and wonderful? Microplastics prevail in snow from the Alps to the Arctic. Sci Adv 5:eaax1157

Best J (2019) Anthropogenic stresses on the world's big rivers. Nat Geosci 12:7-21

Bilotta GS, Brazier RE (2008) Understanding the effects of suspended solids on water chemistry and aquatic biota. Water Res 42:2849 2861

Bilotta GS, Burnside NG, Cheek L, Dunbar MJ, Grove MK, Harrison C, Joyce C, Peacock C, Davy-Bowker J (2012) Developing environment-specific water quality guidelines for suspended particulate matter. Water Res 46:2324-2332

Blais JM, Schindler DW, Muir DCG, Kimpe LE, Donald DB, Rosenberg B (1998) Accumulation of persistent organochlorine compounds in mountains of western Canada. Nature 395:585-588

Blais JM, Schindler DW, Muir DCG, Sharp M, Donald M, Lafrenière M, Braekevelt E, Strachan WMJ, Comba M, Backus S (2010) Melting glacier dominate sources of persistent organochlorines to subalpine Bow Lake in Banff National Park, Canada. Ambio 30:410-415

Borrelli P, Robinson DA, Fleischer LR, Luagto E, Ballabio C, Alewell C, Meusburger K, Modugno S, Schütt B, Ferro V, Bagarelle V, Van Oost K, Montanarella L, Panagos P (2013) An assessment of the global impact of $21^{\text {st }}$ century land use change on soil erosion. Nature Comm. https://doi.org/10.1038/s41467-017-02142-7

Borrelli P, Robinson DA, Panagos P, Lugato E, Yang JE, Alewell C, Wuepper D, Montanarella L, Ballabio C (2020) Land use and climate change impacts on global soil erosion by water (2015-2070). Proc Natl Acad Sci U S A. https://doi.org/10.1073/pnas. 2001403117

Borselli L, Cassi P, Torri D (2008) Prolegomena to sediment and flow connectivity in the landscape: a GIS and field numerical assessment. Catena 75:268-277

Bracken LJ, Croke J (2007) The concept of hydrological connectivity and its contribution to understanding runoff dominated geomorphic systems. Hydrol Process 21:1749-1763

Bracken LJ, Wainwright J, Ali GA, Tetzlaff D, Smith MW, Reaney SM, Roy AG (2013) Concepts of hydrological connectivity: research approaches, pathways and future agendas. Earth Sci Rev 119:17-34

Bracken LJ, Turnbull L, Wainwright J, Bogaart P (2015) Sediment connectivity: a framework for understanding sediment transfer at multiple scales. Earth Surf Process Landf 40:177-188

Brantley SL, Goldhaber MB, Ragnarsdottir KV (2007) Crossing disciplines and scales to understand the Critical Zone. Elements 3:307314

Brazier RE (2004) Quantifying soil erosion by water in the UK: a review of monitoring and modelling approaches. Prog Phys Geogr 28:340 365

Brierley G, Fryirs K, Jain V (2006) Landscape connectivity: 1 the geographic basis of geomorphic applications. Area 38:165-174

Brils J (2008) Sediment monitoring and the European Water Framework Directive. Annali dell Instituto Superiore Di Sanita 44:218-223
Brils J (2020) Including sediment in European River Basin Management Plans - 20 years of work by SedNet. J Soils Sediments 20. https:// doi.org/10.1007/s11368-020-02782-1

Brown LR (1981) World population growth, soil erosion, and food security. Science 214:995-1002

Bussi G, Francés F, Horel E, López-Tarazón JA, Batalla RJ (2014) Modelling the impact of climate change on sediment yield in a highly erodible Mediterranean catchment. J Soils Sediments 14: 1921-1937

Carson R (1962) Silent spring. Houghton Mifflin, Boston

Chaloner DT, Martin KM, Wipfli MS, Ostrem PH, Lamberti GA (2002) Marine carbon and nitrogen in southeastern Alaska stream food webs: evidence from artificial and natural streams. Can J Fish Aquat Sci 59:1257-1265

Church M, Ryder JM (1972) Paraglacial sedimentation: a consideration of fluvial processes conditioned by glaciation. Geol Soc Am Bull 83:3059-3072

Collins AL, Anthony SG (2008) Assessing the likelihood of catchments across England and Wales meeting "good ecological status" due to sediment contributions from agricultural sources. Environ Sci Pol 11:163-170

Collins AL, Walling DE, Leeks GJL (1997) Use of the geochemical record preserved in floodplain deposits to reconstruct recent changes in river basin sediment sources. Geomorphology 19:151-167

Collins AL, Pulley S, Foster IDL, Gellis A, Porto P, Horowitz AJ (2017) Sediment source fingerprinting as an aid to catchment management: a review of the current state of knowledge and a methodological decision-tree for end-users. J Environ Manag 194:86-108

Cooke CA, Balcom PH, Biester H, Wolfe AP (2009) Over three millennia of mercury pollution in the Peruvian Andes. Proc Natl Acad Sci U S A 106:8830-8834

Cooke CA, Martínez-Cortizas A, Bindler R, Gustin ME (2020) Environmental archives of atmospheric $\mathrm{Hg}$ deposition: a review. Sci Total Environ 709:134800

Correll DL (1998) The role of phosphorus in the eutrophication of receiving waters: a review. J Environ Qual 27:261-266

Crutzen PJ (2002) The geology of mankind. Nature 415:23

Crutzen PJ, Stoermer EF (2000) The "Anthropocene". IGBP Newsl 41: $17-18$

D’Haen K, Verstraeten G, Degryse P (2012) Fingerprinting historical sediment fluxes. Prog Phys Geogr 36:154-186

D’Oleire-Oltmanns S, Marzolff I, Peter KD, Ries JB (2012) Unmanned aerial vehicle (UAV) for monitoring soil erosion in Morocco. Remote Sens 4:3390-3416

Dearing JA (1991) Lake sediment records of erosional processes. Hydrobiologia 214:99-106

Delang CO, Yuan Z (2015) China's Green for Grain Program: a review of the largest ecological restoration and rural development program in the World. Springer, Heidelberg

Dercon G, Mabit L, Hancock G, Nguyen ML, Domhofer P, Bacchi OOS, Benmansour M, Bernard C, Froehlich W, Golosov VN, Haciyakupoglu S, Hai PS, Klik A, Lobb DA, Onda Y, Popa N, Rafiq M, Ritchie JC, Schuller P, Shakhashiro A, Wallbrink P, Walling DE, Zapata F, Zhang X (2012) Fallout radionuclide-based techniques for assessing the impact of soil conservation measures on erosion control and soil quality: an overview of the main lessons learnt under an FAO/IAEA Coordinated Research Project. J Environ Radioact 107:78-85

Derry LA, Chadwick OA (2007) Contributions of Earth's atmosphere to soil. Elements 3:333-338

Diamond JM (2005) Collapse: how societies choose to fail or succeed. Penguin, London

Dotterweich M (2013) The history of human-induced soil erosion: geomorphic legacies, early descriptions and research, and the development of soil conservation - a global synopsis. Geomorphology 201: $1-34$ 
Droppo IG (2001) Rethinking what constitutes suspended sediment. Hydrol Process 15:1551-1564

Droppo IG, Liss SN, Williams D, Nelson T, Jaskot C, Trapp B (2009) Dynamic existence of waterborne pathogens within river sediment compartments: implications for water quality regulatory affairs. Environ Sci Technol 43:1737-1743

Dutton CL, Subalusky AL, Hill TD, Aleman JC, Rosi EJ, Onyango KB, Kanuni K, Cousins JA, Staver AC, Post DM (2019) A 2000-year sediment record reveals rapidly changing sedimentation and land use since the 1960s in the Upper Mara-Serengeti Ecosystem. Sci Total Environ 664:148-160

Duxbury JM (1994) The significance of agricultural sources of greenhouse gases. Fertilizer Res 38:151-163

EC (2000) Directive 2000/60/EC of the European Parliament and of the council establishing a framework for community action in the field of water policy (Water Framework Directive). European Commission, Brussels

EC (2007) Directive 2007/60/EC of the European Parliament and of the council of 23 October 2007 on the assessment and management of flood risks (Floods Directive). European Commission, Brussels

Elbaz-Poulichet F, Guedon S, Anne-Lise D, Freydier R, Perrot V, Rossi M, Piot C, Delpoux S, Sabatier S (2020) A 10,000-year record of trace metal and metalloid $(\mathrm{Cu}, \mathrm{Hg}, \mathrm{Sb}, \mathrm{Pb})$ deposition in a western Alpine lake (Lake Robert, France): deciphering local and regional mining contamination. Quat Sci Rev 228:106076. https://doi.org/10. 1016/j.quascirev.2019.106076

Eriksen M, Lebreton LCM, Carson HS, Thiel M, Moore CJ, Borerro JC, Galgani F, Ryan PG, Reisser J (2014) Plastic pollution in the world's oceans: more than 5 trillion pieces weighing over 25,000 tons afloat at sea. PLoS One 9:c111913

Evrard O, Chartin C, Onda Y, Lepage H, Lefèvre I, Ayrault S, Ottlé C, Bonté P (2013) Evolution of radioactive dose rates in fresh sediment deposits along coastal rivers draining Fukushima contamination plume. Sci Rep 3:3079. https://doi.org/10.1038/srep03079

Evrard O, Laceby JP, Lepage H, Onda Y, Cerdan O, Ayrault S (2015) Radiocesium transfer from hillslopes to the Pacific Ocean after the Fukushima Nuclear Power Plant accident: a review. J Environ Radioact 148:92-110

Evrard O, Chaboche P-A, Ramon R, Foucher A, Laceby JP (2020) A global review of sediment source fingerprinting research incorporating fallout radiocesium $\left({ }^{137} \mathrm{Cs}\right)$. Geomorphology 362:107103

Fan S, Springer FE (1993) Major sedimentation issues at the Federal Energy Regulatory Commission. In: Fan S, Morris G (eds) Notes on Sediment Management in Reservoirs. Water Resources Publication, Colorado

Fang H (2019) Temporal changes in suspended sediment transport during the past five decades in a mountainous catchment, eastern China. J Soils Sediments 19:4073-4085

FAO (2019a) Soil erosion: the greatest challenge to sustainable soil management. Food and Agriculture Organization of the United Nations, Rome, Italy, $100 \mathrm{pp}$

FAO (2019b) Soil erosion must be stopped "to save our future", says UN agriculture agency. Food and Agriculture Organization of the United Nations. https://news.un.org/en/story/2019/12/1052831. Accessed Sept 2020

FAO and ITPS (2015) Status of the world's soil resources - main report. Food and Agriculture Organization of the United Nations and Intergovernmental Technical Panel on Soils. Rome, Italy, 649 pp

Ferro V, Porto P (2000) Sediment delivery distributed (SEDD) model. J Hydraul Eng 5:411-422

Flanner MG, Zender CS, Richardson TJ, Rasch PJ (2007) Present-day climate forcing and response from black carbon in snow. J Geophys Res 112. https://doi.org/10.1029/2006JD008003

Flato G, Marotzke J, Abiodun B, Bracannot P, Chou SC, Collins W, Cox P, Driouech F, Emori S, Eyring V, Forest C, Gleckler P, Guilyardi E, Jakob C, Kattsov V, Reason C, Rummukainen M (2013) Evaluation of climate models. In: Stocker TF, Qin D, Plattner G-K, Tignor M, Allen SK, Boschung J, Nauels A, Xia Y, Bex V, Midgley PM (Eds) Climate change 2013: The physical science basis. Contribution of Working Group I to the Fifth Assessment Report of the Intergovernmental Panel on Climate Change. Cambridge University Press, Cambridge, pp 741-866

Förstner U (2002) Sediments and the European Water Framework Directive. J Soils Sediments 2:54

Förstner U, Owens PN (2007) Sediment quantity and quality issues in river basins. In: Westrich B, Förstner U (eds) Sediment dynamics and pollutant mobility in rivers: an interdisciplinary approach. Springer, Berlin, pp 1-15

Förstner U, Wittman GTW (1979) Metal pollution in the aquatic environment. Springer-Verlag, New York

Foster IDL, Charlesworth SM (1996) Heavy metals in the hydrological cycle: trends and explanation. Hydrol Process 10:227-261

Foster IDL, Lees JA (1999) Changing headwater suspended sediment yields in the LOIS catchments over the last century: a paleolimnological approach. Hydrol Process 13:1137-1153

Foster IDL, Collins AL, Naden PS, Sear DA, Jones JI, Zhang Y (2011) The potential for paleolimnology to determine historic sediment delivery to rivers. J Paleolimnol 45:287-306

Fryirs K (2013) (Dis)connectivity in catchment sediment cascades: a fresh look at the sediment delivery problem. Earth Surf Process Landf 38:30-46

Fryirs KA, Brierley GJ, Preston NJ, Kasai M (2007) Buffers, blankets and barriers: the (dis)connectivity of catchment-scale sediment cascades. Catena 70:49-67

Galbreath PF, Bisbee MA Jr, Dompier DW, Kamphaus CM, Newsome TH (2014) Extirpation and tribal reintroduction of Coho salmon to the interior of the Columbia River Basin. Fisheries 39:77-87

Gallagher L, MacDonald RW, Paton DW (2004) The historical record of metals in sediments from six lakes in the Fraser River Basin, British Columbia. Water Soil Air Pollut 152:257-282

García-Comendador J, Fortesa J, Calsamiglia A, Garcias F, Estrany J (2017) Source ascription in bed sediments of a Mediterranean temporary stream after the first post-fire flush. J Soils Sediments 17: 2582-2595

Gateuille D, Evrard O, Lefevre I, Moreau-Guigon E, Alliot F, Chevreuil M, Mouchel JM (2014) Mass balance and decontamination times of polycyclic aromatic hydrocarbons in rural nested catchments of an early industrialized region (Seine River basin, France). Sci Total Environ 470:608-617

Gateuille D, Owens PN, Petticrew EL, Booth BP, French TA, Déry SJ (2019) Determining contemporary and historical sediment sources in a large drainage basin impacted by cumulative effects: the regulated Nechako River, British Columbia, Canada. J Soils Sediments 19:3357-3373

Gilbert GK (1917) Hydraulic mining debris in the Sierra Nevada. U.S. Geological Survey Professional Paper 150, USGS, Washington

Glikson A (2013) Fire and human evolution: the deep-time blueprints of the Anthropocene. Anthropocene 3:89-92

Globe and Mail (2019) Louisiana's sinking feeling: as coastline vanishes, locals scramble to save what they can. The Globe and Mail 7(2019): A10-A11

Grill G, Lehner B, Thieme M, Geenen B, Tickner D, Antonelli F, Babu S, Borrelli P, Cheng L, Crochetiere H, Macedo HE, Filgueiras R, Goichot M, Higgins J, Hogan Z, Lip B, McClain ME, Meng J, Mulligan M, Nilsso C, Olden JD, Opperman JJ, Petry P, Liermann CR, Saenz L, Salinas-Rodriguez S, Schelle P, Schmitt RJP, Snider J, Tan F, Tockner K, Valdujo PH, van Soesbergen A, Zarfl C (2019) Mapping the world's free-flowing rivers. Nature 569:215-221

Guzman G, Quinton JN, Nearing MA, Mabit L, Gómez JA (2013) Sediment tracers in water erosion studies: current approaches and challenges. J Soils Sediments 13:816-833 
Habersack H, Hein T, Stanica A, Liska I, Mair R, Jäger E, Hauer C, Bradley C (2016) Challenges of river basin management: current status of, and prospects for, the River Danube from a river engineering perspective. Sci Total Environ 543:828-845

Haddadchi A, Ryder DS, Evrard O, Olley J (2013) Sediment fingerprinting in fluvial systems: a review of tracers, sediment sources and mixing models. Int J Sediment Res 28:560-578

Hansen J, Johnson D, Lacis A, Lebedeff S, Lee P, Rind D, Russell G (1981) Climate impact of increasing atmospheric carbon dioxide. Science 213:957-966

Hassan MA, Gottesfeld AS, Montgomery DR, Tunnicliffe JF, Clarke GKC, Wynn G, Jones-Cox H, Poirier R, MacIssac E, Herunter H, Macdonald SJ (2008) Salmon-driven bed load transport and bed morphology in mountain streams. Geophys Res Lett 35:L04405

Hatam I, Petticrew EL, French TD, Owens PN, Laval B, Baldwin S (2019) The bacterial community of Quesnel Lake sediments impacted by a catastrophic mine tailings spill differ in composition from those at undisturbed locations - two years post-spill. Sci Rep 9: 2705. https://doi.org/10.1038/s41598-019-38909-9

Hays JD, Imbie J, Shackleton NJ (1976) Variations in the Earth's orbit: pacemaker of ice ages. Science 194:1121-1132

Hilderbrand G, Farley S, Schwartz C, Robbins C (2004) Importance of salmon to wildlife: implications for integrated management. Ursus $15: 1-9$

Holling CS (ed) (1978) Adaptive environmental assessment and management. Wiley, London

Hooke RL (2000) On the history of humans as geologic agents. Geology 28:843-846

Horowitz AJ (1991) A primer on sediment-trace element geochemistry. Lewis, Boca Raton

Horowitz AJ (2010) A quarter century of declining suspended sediment fluxes in the Mississippi River and the effect of the 1993 flood. Hydrol Process 24:13-34

Houwenhuyse S, Macke E, Reyser L, Bulteel L, Decaestecker E (2018) Back to the future in a petri dish: origin and impact of resurrected microbes in natural populations. Evol Appl 11:29-41

Hu J, Zhao G, Mu X, Tian P, Gao P, Sun W (2019) Quantifying the impacts of human activities on runoff and sediment load changes in a Loess Plateau catchment, China. J Soils Sediments 19:38663880

Hudson-Edwards KA, Macklin MG, Taylor MP (1999) 2000 years of sediment-borne heavy metal storage in the Yorkshire Ouse basin, NE England, UK. Hydrol Process 13:1087-1102

Hurley R, Woodward J, Rothwell JJ (2018) Microplastic contamination of river beds significantly reduced by catchment-wide flooding. Nat Geosci 11:251-257

Ibáñez C, Alcaraz C, Caiola N, Prado P, Trobajo R, Benito X, Day JW, Reyes E, Syvitski JPM (2019) Basin-scale land use impacts on world deltas: humans vs natural forcing. Glob Planet Chang 173: 24-32

Jenny J-P, Koirala S, Gregory-Eaves I, Francus P, Niemann C, Ahrens B, Brovkin BA, Ojala AEK, Normandeau A, Zolitschka B, Carvalhais N (2019) Human and climate global-scale imprint on sediment transfer during the Holocene. Proc Natl Acad Sci U S A 116: 22972-22976

Johnson MF, Rice SP, Reid I (2011) Increase in coarse sediment transport associated with disturbance of gravel river beds by signal crayfish (Pacifastacus leniusculus). Earth Surf Process Landf 36:1680-1692

Jones CG, Lawton JH, Shachak M (1984) Organisms as ecosystem engineers. Oikos 69:373-386

Jones JI, Collins AL, Naden PS, Sear DA (2012a) The relationship between fine sediment and macrophytes in rivers. River Res Appl 28: 1006-1018

Jones JI, Murphy JF, Collins AL, Sear DA, Naden PS, Armitage PD (2012b) The impact of fine sediment on macro-invertebrates. River Res Appl 28:1055-1071
Jones JI, Duerdorh CP, Collins AL, Naden PS, Sear DA (2014) Interactions between diatoms and fine sediment. Hydrol Process 28:1226-1237

Kalnay E, Cai M (2003) Impact of urbanization and land-use change on climate. Nature 423:528-531

Keegan KM, Albert MR, McConnell JR, Baker I (2014) Climate change and forest fires synergistically drive widespread melt events of the Greenland ice sheet. Proc Natl Acad Sci U S A 111:7964-7967

Keesstra SD, Nunes JP, Saco P, Parsons T, Poeppl R, Masselink R, Cerda A (2018) The way forward: can connectivity be useful to design better measuring and modelling schemes for water and sediment dynamics? Sci Total Environ 644:1557-1572

Keesstra SD, Davis J, Masselink RH, Casalf J, Peeters ET, Dijksma R (2019) Coupling hysterysis analysis with sediment and hydrological connectivity in three agricultural catchments in Navarre, Spain. J Soils Sediments 19:1598-1612

Kemp P, Sear D, Collins A, Naden P, Jones I (2011) The impacts of fine sediment on riverine fish. Hydrol Process 25:1800-1821

Khodadadi M, Mabit L, Zaman M, Porto P, Gorji M (2019) Using ${ }^{137} \mathrm{Cs}$ and ${ }^{210} \mathrm{~Pb}$ measurements to explore the effectiveness of soil conservation measures in semi-arid lands: a case study in the Kouhin region of Iran. J Soils Sediments 19:1203-1213

Kjelland ME, Woodley CM, Swannack TM, Smith DL (2015) A review of the potential effects of suspended sediment on fishes: potential dredging-related physiological, behavioral, and transgenerational implications. Environ Syst Decis 35:334-350

Kondolf GM (1997) Hungry waters: effects of dams and gravel mining on river channels. Environ Manag 21:533-551

Kondolf GM, Gao YX, Annandale GW, Morris GL, Jiang EH, Zhang JH, Cao YT, Carling P, Fu KD, Guo QC, Hotchkiss R, Peteuil C, Sumi T, Wang HW, Wang ZM, Wei ZL, Wu BS, Wu CP, Yang CT (2014) Sustainable sediment management in reservoirs and regulated rivers: experiences from five continents. Earths Future 2:256-280

Kondolf GM, Schmitt RJP, Carling P, Darby S, Arias M, Bizzi S, Castelletti A, Cochrane TA, Gibson S, Kummu M, Oeurng C, Zan RB, Wild T (2019) Changing sediment budget of the Mekong: cumulative threats and management strategies for a large river basin. Sci Total Environ 625:114-134

Kossoff D, Dubbin WE, Alfredsson M, Edwards SJ, Macklin MG, Hudson-Edwards KA (2014) Mine tailings dams: characteristics, failure, environmental impacts and remediation. Appl Geochem 51:229-245

Lal R (2003) Soil erosion and the global carbon budget. Environ Int 29: $437-450$

Lane SN, Tayefi V, Reid SC, Yu D, Hardy RJ (2007) Interactions between sediment delivery, channel change, climate change and flood risk in a temperate upland environment. Earth Surf Process Landf 32:429-446

Lawler DM, Grove JR, Couperthwaite JS, Leeks GJL (1999) Downstream change in bank erosion rates in the Swale-Ouse system, northern England. Hydrol Process 13:977-992

Le Quéré C, Andrew RM, Friedlingstein P et al (2018) Global carbon budget 2018. Earth Syst Sci Data 10:2141-2194

Lebreton LCM, Van der Zwet J, Damsteeg JW, Slat B, Andrady A, Reisser J (2017) River plastic emissions to the world's oceans. Nat Commun 8:15611

Leopold LB (1956) Land use and sediment yield. In: Thomas WL Jr (ed) Man's role in changing the face of the Earth. University of Chicago Press, Chicago, pp 584-606

Lewis SL, Maslin MA (2015) Defining the Anthropocene. Nature 519: $171-180$

Lewis SL, Maslin MA (2018) The human planet: how we created the Anthropocene. Pelican, Penguin Books, UK

Li S, Lobb DA, Lindstrom MJ, Farenhorst A (2007) Tillage and water erosion on different landscapes in the northern North American 
Great Plains evaluated using ${ }^{137} \mathrm{Cs}$ technique and soil erosion models. Catena 70:493-505

Li S, Lobb DA, Kachanoski RG, McConkey BG (2011) Comparing the use of the traditional and repeated sampling-approach of the ${ }^{137} \mathrm{Cs}$ technique in soil erosion estimation. Geoderma 160:324-335

Li L, Ni J, Chang F, Yue Y, Frolova N, Magritsky D, Borthwick AGL, Ciais P, Wang Y, Zheng C, Walling DE (2020a) Global trends in water and sediment fluxes in the world's large rivers. Sci Bull 65: 62-69

Li T, Wang S, Liu Y, Fu B, Zhao W (2020b) A retrospective analysis on changes in sediment flux in the Mississippi River system: trends, driving forces, and implications. J Soils Sediments 20:1719-1729

Liu C, Walling DE, He Y (2018) Review: The international sediment initiative case studies of sediment problems in river basins and their management. Int J Sediment Res 33:216-219

Lockhart WL, Mcdonald RW, Outridge PM, Wilkinson P, DeLaronde JB, Rudd JWM (2000) Tests of the fidelity of lake sediment core records of mercury deposition to known histories of mercury contamination. Sci Total Environ 260:171-180

Luoma SN, Rainbow PS (2008) Metal contamination in aquatic environments: science and lateral management. Cambridge University Press, Cambridge

Mabit L, Benmansour M, Walling DE (2008) Comparative advantages and limitations of the fallout radionuclides ${ }^{137} \mathrm{Cs},{ }^{210} \mathrm{~Pb}_{\mathrm{ex}}$ and ${ }^{7} \mathrm{Be}$ for assessing soil erosion and redistribution. J Environ Radioact 99: $1799-1807$

MacDonald DD, Ingersoll CG, Berger TA (2000) Development and evaluation of consensus-based sediment quality guidelines for freshwater ecosystems. Arch Environ Contam Toxicol 39:20-31

Mahoney DT, Fox J, Al-Aamery N, Clare E (2020a) Integrating connectivity theory within watershed modelling part I: model formulation and investigating the timing of sediment connectivity. Sci Total Environ 740:140385

Mahoney DT, Fox J, Al-Aamery N, Clare E (2020b) Integrating connectivity theory within watershed modelling part II: application and evaluating structural and functional connectivity. Sci Total Environ 740:140386

Mahowald NM, Baker AR, Bergametti G, Brooks N, Duce RA, Jickells TD, Kubilay N, Prospero JM, Tegen I (2005) Atmospheric global dust cycle and iron inputs to the ocean. Glob Biogeochem Cycles 19:GB4025

Martínez-Cortizas A, Pontevedra-Pombal X, García-Rodeja E, NóvoaMuñoz JC, Shotyk W (1999) Mercury in a Spanish peat bog: archive of climate change and atmospheric metal deposition. Science 284: 939-942

McAdam SO, Walters CJ, Nistor C (2005) Linkages between White Sturgeon recruitment and altered bed substrates in the Nechako River, Canada. Trans Am Fish Soc 134:1448-1456

McClain ME, Boyer EW, Dent CL, Gergel SE, Grimm NB, Groffman PM, Hart SC, Harvey JW, Johnston CA, Mayorga E, McDowell WH, Pinay G (2003) Biogeochemical hot spots and hot moments at the interface of terrestrial and aquatic ecosystems. Ecosystems 6: 301-312

McConnell JR, Aristarain AJ, Banta JR, Edwards PR, Simões JC (2007a) 20th-Century doubling in dust archived in an Antarctic Peninsula ice core parallels climate change and desertification in South America. Proc Natl Acad Sci U S A 104:5743-5748

McConnell JR, Edwards R, Kok GL, Flanner MG, Zender CS, Saltzman ES, Banta JR, Pasteris DR, Carter MM, Kahl JDW (2007b) 20thCentury industrial black carbon emissions altered Arctic climate forcing. Science 317:1381-1384

Meade RH, Moody JA (2010) Causes for the decline in suspendedsediment discharge in the Mississippi River system, 1940-2007. Hydrol Process 24:35-49

Melaku ND, Renschler CS, Holzmann H, Strohmeier S, Bayu W, Zucca C, Ziadat F, Klik A (2018) Prediction of soil and water conservation structure impacts on runoff and erosion processes using SWAT model in the northern Ethiopian highlands. J Soils Sediments 18: $1743-1755$

Meredith M, Sommerkorn M, Cassotta S, Derksen C, Ekaykin A, Hallowed A, Kofinas G, Mackintosh A, Melbourne-Thomas J, Muelbert MMC, Ottersen G, Pritchard H, Schuur EAG (2019) Polar Regions. In: Pörtner H-O, Roberts DC, Masson-Delmotte V, Zhai P, Tignor M, Ploczanska E, Mintenbeck K, Alegria A, Nicolai M, Okem A, Petzold J, Rama B, Weye NM (eds), IPCC special report on the ocean and cryosphere in a changing climate (in press), pp 203-320. https://www.ipcc.ch/srocc/. Accessed Sept 2020

Merritt WS, Letcher RA, Jakeman AL (2003) A review of erosion and sediment transport models. Environ Model Softw 18:761-799

Meusburger K, Evrard O, Alewell C, Borelli P, Cinelli G, Ketterer M, Mabit L, Panagos P, van Oost K, Ballabio C (2020) Plutonium aided reconstruction of atmospheric fallout in European topsoils. Sci Rep 10:11858. https://doi.org/10.1038/s41598-020-68736-2

Miller JR, Orbock Miller SM (2007) Contaminated rivers. Springer, Dordrecht

Milliman JD, Farnsworth KL (2011) River discharge to the coastal ocean: a global synthesis. Cambridge University Press, Cambridge

Milliman JD, Syvitski JPM (1992) Geomorphic/tectonic control of sediment discharge to the ocean: the importance of small mountain rivers. J Geol 100:525-544

Milner AM, Khamis K, Battin TJ, Brittain JE, Barrand NE, Fureder L, Cauvy-Fraunie S, Gislason GM, Gisli JD, Hannah DM, Hodson AJ, Hood E, Lencioni V, Olafsson JS, Robinson CT, Tranter M, Brown LE (2017) Glacier shrinkage driving global changes in downstream systems. Proc Natl Acad Sci U S A 114:9770-9778

Mitchell A (2009) Sea sick: The global ocean in crisis. McClelland and Stewart Ltd, Toronto

Montanarella L, Pennock DJ, McKenzie N et al (2016) World's soils are under threat. Soil 2:79-82

Montgomery DR (2003) King of fish: the thousand-year run of salmon. Westview Press, Boulder

Montgomery DR (2007a) Soil erosion and agricultural sustainability. Proc Natl Acad Sci U S A 104:13268-13272

Montgomery DR (2007b) Dirt: the erosion of civilizations. University of California Press, Berkley

Moore RD, Fleming SW, Menounos B, Wheate R, Fountain A, Stahl K, Holm K, Jakob M (2009) Glacier change in western North America: influences on hydrology, geomorphic hazards and water quality. Hydrol Process 23:42-61

Morgan RPC (2005) Soil erosion and conservation, 3rd edn. Blackwell Publishing, Oxford

Morris GL (2020) Classification of management alternatives to combat reservoir sedimentation. Water 12:861. https://doi.org/10.3390/ w12030861

Myhre G, Shindell D, Bréon F-M, Collins W, Fuglestveld J, Huang J, Koch D, Lamarque J-F, Lee D, Mendoza B, Nakajima T, Robock A, Stephens G, Takemura T, Zhang H (2013) Anthropogenic and natural radiative forcing. In: Stocker TF, Qin D, Pattner G-K, Tignor M, Allen SK, Boschung J, Naules A, Xia Y, Bex V, Midgley PM (eds) Climate Change 2013: The physical science basis. Contribution of Working Group I to the Fifth Assessment Report of the Intergovernmental Panel on Climate Change. Cambridge University Press, Cambridge, pp. 659-740

Naiman RJ, Bilby RE, Schindler DE, Helfield JM (2002) Pacific salmon, nutrients, and the dynamics of freshwater and riparian ecosystems. Ecosystems 5:399-417

Najafi S, Dragovich D, Heckmann T, Sadeghi SH (2020) Sediment connectivity concepts and approaches. Catena 196:104880

Neto ND, Evangelista H, Condom T, Rabatel A, Ginot P (2019) Amazonian biomass burning enhances tropical Andean glaciers melting. Sci Rep 9:16914. https://doi.org/10.1038/s41598-01953284-1 
Newcombe CP, MacDonald DD (1991) Effects of suspended sediment on aquatic ecosystems. N Amer J Fish Manag 11:72-82

Nienhuis JH, Ashton AD, Edmonds DA, Hoitink AJF, Kettner AJ, Rowland JC, Törnqvist TE (2020) Global-scale human impact on delta morphology has led to net land area gain. Nature 577. https:// doi.org/10.1038/s41586-019-1905-9

Noble M, Duncan P, Perry D, Prosper K, Rose D, Schnierer S, Tipa G, Willimas E, Woods R, Pittock J (2016) Culturally significant fisheries: keystones for management of freshwater social-ecological systems. Ecol Soc 21:22. https://doi.org/10.5751/ES-08353-210222

Nones M (2019) Dealing with sediment transport in flood risk management. Acta Geophysica 67:677-685

Nones M, Gerstgraser C, Wharton G (2017) Consideration of hydromorphology and sediment in the implementation of the EU water framework and floods directives: a comparative analysis of selected EU member states. Water Environ J 31:324-329

Nriagu JO, Pacyna JM (1988) Quantitative assessment of worldwide contamination of air, water and soils by trace-metals. Nature 333: 134-139

Oldfield F (1977) Lakes and their drainage basins as units of sediment based ecological study. Prog Phys Geogr 1:460-504

Oliver DM, Clegg CD, Haygarth PM, Heathwaite AL (2005) Assessing the potential for pathogen transfer from grassland soils to surface waters. Adv Agron 85:125-180

Owens PN (2005) Conceptual models and budgets for sediment management at the river basin scale. J Soils Sediments 5:201-212

Owens PN (2008) Sediment behaviour, functions and management. In: Owens PN (ed) Sustainable management of sediment resources: sediment management at the river basin scale. Elsevier, Amsterdam, pp 1-29

Owens PN (2009) Adaptive management frameworks for natural resource management at the landscape scale: implications and applications for sediment resources. J Soils Sediments 9:578-593

Owens PN, Walling DE (2002) Changes in sediment sources and floodplain deposition rates in the catchment of the River Tweed, Scotland, over the last 100 years: the impact of climate and land use change. Earth Surf Process Landf 27:403-423

Owens PN, Walling DE (2003) Temporal changes in the metal and phosphorus content of suspended sediment transport by Yorkshire Rivers, U.K., over the last 100 years, as record by overbank floodplain deposits. Water Air Soil Pollut 494:185-191

Owens PN, Walling DE, Leeks GJL (1999) Use of floodplain sediment cores to investigate recent historical changes in overbank sedimentation rates and sediment sources in the catchment of the River Ouse, Yorkshire, UK. Catena 36:21-47

Owens PN, Batalla RJ, Collins AJ, Gomez B, Hicks DM, Horowitz AJ, Kondolf GM, Marden M, Page MJ, Peacock DH, Petticrew EL, Salomons W, Trustrum NA (2005) Fine-grained sediment in river systems: environmental significance and management issues. River Res Appl 21:693-717

Owens PN, Blake WH, Giles TR, Williams ND (2012) Determining the effects of wildfire on sediment sources using ${ }^{137} \mathrm{Cs}$ and unsupported ${ }^{210} \mathrm{~Pb}$ : the role of natural landscape disturbances and driving forces. J Soils Sediments 12:982-994

Owens PN, Blake WH, Gasper L, Gateuille D, Koiter AJ, Lobb DA, Petticrew EL, Reiffarth DG, Smith HG, Woodward JC (2016) Fingerprinting and tracing the sources of soils and sediments: Earth and ocean science, geoarchaeological, forensic, and human health applications. Earth Sci Rev 162:1-23

Owens PN, Blake WH, Millward GE (2019a) Extreme levels of fallout radionuclides and other contaminants in glacial sediment (cryoconite) and implications for downstream aquatic ecosystems. Sci Rep 9:12531. https://doi.org/10.1038/s41598-019-48873-Z

Owens PN, Gateuille D, Petticrew EL, Booth B, French TA (2019b) Sediment-associated organopollutants, metals and nutrients in the
Nechako River, British Columbia: a current study with synthesis of historical data. Can Water Resour J 44:42-64

Page MJ, Trustrum NA (1997) A late Holocene lake sediment record of the erosion response to land use change in a steepland catchment, New Zealand. Zeitschrift für Geomorph NF 41:369-392

Paine RT (1966) Food web complexity and species diversity. Am Nat 100:65-75

Palazón L, Navas N (2016) Land use sediment production response under different climatic conditions in an alpine-prealpine catchment. Catena 137:244-255

Pandey A, Himanshu SK, Mishra SK, Singh VP (2016) Physically based soil erosion and sediment yield models revised. Catena 147:595620

Paterson DM, Hope JA, Kenworthy J, Biles CL, Gerbersdorf SU (2018) Form, function and physics: the ecology of biogenic stabilisation. $\mathrm{J}$ Soils Sediments 18:3044-3054

Persaud D, Jaagumagi R, Hayton A (1993) Guidelines for the protection and management of aquatic sediment quality in Ontario. Water Resources Branch, Ontario Ministry of Environment, Ottawa

Petticrew EL, Kalff J (1992) Water-flow and clay retention in submerged aquatic beds. Can J Fish Aquat Sci 49:2483-2489

Pimental D (2006) Soil erosion: a food and environmental threat. Environ Devel Sust 8:119-137

Plaza C, Pegoraro E, Bracho R, Celis G, Crummer KG, Hutchings JA, Pries CEH, Mauritz M, Natali SM, Salmon VG, Schädel C, Webb EE, Schuur EAG (2019) Direct observation of permafrost degradation and rapid soil carbon loss in tundra. Nat Geosci 12:627-631

Poeppl RE, Fryirs KA, Tunnicliffe J, Brierley GJ (2020) Managing sediment (dis)connectivity in fluvial systems. Sci Total Environ 736: 139627

Poesen J (2018) Soil erosion in the Anthropocene: research needs. Earth Surf Process Landf 43:64-84

Porto P, Walling DE, Callegari G (2018) Using repeated ${ }^{137} \mathrm{Cs}$ and ${ }^{210} \mathrm{~Pb}_{\mathrm{xs}}$ measurements to establish sediment budgets for different time windows and explore the effect of connectivity on soil erosion rates in a small experimental catchment in southern Italy. Land Degrad Dev 29:1819-1832

Pyle GG, Rajotte JW, Couture P (2005) Effects of industrial metals on wild fish populations along a metal contamination gradient. Ecotoxicol Environ Saf 61:287-312

Queiroz HM, Nóbrega GN, Ferreira TO, Almeida LS, Romero TB, Santaella ST (2018) The Samarco mine tailing disaster: a possible time-bomb for heavy metals contamination? Sci Total Environ 637: 498-506

Rahman F, Langford KH, Scrimshaw MD, Lester JN (2001) Polybrominated diphenyl ether (PBDE) flame retardants. Sci Total Environ 275:1-17

Randle T, Morris G, Whelan M, Baker B, Annandale G, Hotchkiss R, Boyd P, Minear JT, Ekren S, Collins K, Altinakar M, Fripp J, Jonas M, Juracek K, Kimbrel S, Kondolf M, Raitt D, Weirich F, Eidson D, Shelley J, Vermeeren R, Wegner D, Nelson P, Jensen K, Tullos D (2019) Reservoir sediment management: building a legacy of sustainable water storage reservoirs. In: National reservoir sedimentation and sustainability white paper, SEDHYD Inc., Denver, Colorado, USA

Rex JF, Petticrew EL (2008) Delivery of marine-derived nutrients to streambeds by Pacific salmon. Nat Geosci 1:840-843

Rickson RJ (2014) Can control of soil erosion mitigate water pollution by sediments? Sci Total Environ 468-469:1187-1197

Roberts N, Fyfe RM, Woodbridge J, Gaillard M-J, Davis BAS, Kaplan JO, Marquer L, Mazier F, Nielsen AB, Sugita S, Trondman A-K, Leydet M (2018) Europe's lost forests: a pollen-based synthesis for the last 11,000 years. Sci Rep 8:716. https://doi.org/10.1038/ s41598-017-18646-7 
Robertson GP, Paul EA, Harwood RR (2000) Greenhouse gases in intensive agriculture: contributions of individual gases to the radiative forcing of the atmosphere. Science 289:1922-1925

Ruddiman WF (2018) Three flaws in defining a formal "Anthropocene". Prog Phys Geogr 42:451-461

Ryan PA (1991) Environmental effects of sediment on New Zealand streams: a review. New Zeal J Marine Freshwat Res 25:207-221

Salomons W, Förstner U (1984) Metals in the hydrocycle. SpringerVerlag, Berlin

Sassi HP, van Ogtrop F, Morrison CM, Zhou K, Duan JG, Gerba CP (2020) Sediment re-suspension as a potential mechanism for viral and bacterial contaminants. J Environ Sci Health A. https://doi.org/ $10.1080 / 10934529.2020 .1796118$

Schiefer E, Petticrew EL, Immell R, Hassan MA, Sonderegger DL (2013) Land use and climate change impacts on lake sedimentation rates in western Canada. Anthropocene 3:61-71

Schindler DW (1977) Evolution of phosphorus limitation in lakes. Science 195:260-262

Schmidt V, Krauth T, Wagner S (2017) Export of plastic debris by rivers into the sea. Environ Sci Technol 51:12246-12253

Schuur EAG, Abbott B, the Permafrost Carbon Network (2011) Climate change: high risk of permafrost thaw. Nature 480:32-33

Schuur EAG, McGuire AD, Schädel C, Grosse G, Harden JW, Hayes DJ, Hugelius G, Koven CD, Kuhry P, Lawrence DM, Natali SM, Olefelt D, Romanovsky VE, Schaefer K, Turetsky MR, Treat CC, Vonk JE (2015) Climate change and the permafrost carbon feedback. Nature 520:171-178

Shakesby RA (1993) The erosion bridge: a device for micro-profiling soil surfaces. Earth Surf Process Landf 18:823-827

Slaymaker O (2003) The sediment budget as a conceptual framework and management tool. Hydrobiologia 494:71-82

Slob AFL, Eenhoorn J, Ellen GJ, Gomez CM, Kind J, van der Vlies J (2008) Costs and benefits of sediment management. In: Owens PN (ed) Sustainable management of sediment resources: Sediment management at the river basin scale. Elsevier, Amsterdam, pp 175-197

Smil V (2000) Phosphorus in the environment: natural flows and human interferences. Annu Rev Energy Environ 25:53-88

Smith TA, Owens PN (2014) Individual and cumulative effects of agriculture, forestry and metal mining activities on the metal and phosphorus content of fine-grained sediment; Quesnel River basin, British Columbia, Canada. Sci Total Environ 496:435-442

Smith HG, Sheridan GJ, Lane PNJ, Noske PJ, Heijns H (2011) Changes to sediment sources following wildfire in a forested upland catchment, southeastern Australia. Hydrol Process 25:2878-2889

Stallard RF (1998) Terrestrial sedimentation and the carbon cycle: Coupling weathering and erosion to carbon burial. Glob Biogeochem Cycles 12:231-257

Steffen W, Broadgate W, Deutsch L, Gaffney O, Ludwig C (2015) The trajectory of the Anthropocene: the Great Acceleration. Anthropocene Rev 2:81-98

Syvitski JPM, Vörösmarty CJ, Kettner AJ, Green P (2005) Impact of humans on the flux of terrestrial sediment to the global ocean. Science 308:376-380

Thiebault T, Chassiot L, Fougère L, Destandau E, Simonneau A, Van Beek P, Souhaut M, Chapron E (2017) Record of pharmaceutical products in river sediments: a powerful tool to assess the environmental impact of urban management. Anthropocene 18:47-56

Thomas WL Jr (ed) (1956) Man's role in changing the face of the Earth. University of Chicago Press, Chicago

Tiessen KHD, Li S, Lobb DA, Mehuys GR, Rees HW, Chow TI (2009) Using repeated measurements of ${ }^{137} \mathrm{Cs}$ and modelling to identify spatial patterns of tillage and water erosion with potato production in Atlantic Canada. Geoderma 153:104-118

Trimble SW (1983) A sediment budget for Coon Creek basin in the Driftless Area, Wisconsin, 1853-1977. Amer J Sci 283:454-474
Turetsky MR, Abbott BW, Jones MC, Anthony KW, Olefeldt D, Schuur EAG, Koven C, McGuire AD, Grosse G, Kuhry P, Hugelius G, Lawrence DM, Gibson C, Sannel ABK (2019) Permafrost collapse is accelerating carbon release. Nature 569:32-34

Turetsky MR, Abbott BW, Jones MC, Anthony KW, Olefeldt D, Schuur EAG, Grosse G, Kuhry P, Hugelius G, Koven C, Lawrence DM, Gibson C, Sannel ABK, McGuire AD (2020) Carbon release through abrupt permafrost thaw. Nat Geosci 13:38-42

Turner S, Horton AA, Rose NL, Hall C (2019) A temporal sediment record of microplastics in an urban lake, London, UK. J Paleolimnol 61:449-462

United Nations (2013) What in water security? UN-Water, United Nations, New York, USA

United Nations (2018) Sustainable development goal 6. Synthesis Report 2018 on Water and Sanitation. United Nations, New York, USA

Van der Perk M, Blake WH, Eisma M (2008) Decision support tools for sediment management. In: Owens PN (ed) Sustainable management of sediment resources: sediment management at the river basin scale. Elsevier, Amsterdam, pp 137-173

Van Oost K, Quine TA, Govers G, De Gryze S, Six J, Harden JW, Ritchie JC, McCarthy GW, Heckrath G, Kosmas C, Giraldez JV, Margues da Silva JR, Merckx R (2007) The impact of agricultural soil erosion on the global carbon cycle. Science 318:626-629

Van Rompaey AJJ, Verstraeten G, Van Oost K, Govers G, Poesen J (2001) Modelling mean annual sediment yield using a distributed approach. Earth Surf Process Landf 26:1221-1126

Vanwalleghem T, Gómez JA, Infante Amate J, González de Molina M, Vanderlinden K, Guzmán G, Laguna A, Giráldez JV (2017) Impact of historical land use and soil management change on soil erosion and agricultural sustainability during the Anthropocene. Anthropocene 17:13-29

Venter O, Sanderson EW, Magrach A, Allan JR, Beher J, Jones KR, Possingham HP, Laurence WF, Wood P, Fekete BM, Levy MA, Watson JEM (2016) Sixteen years of change in the global terrestrial human footprint and implications for biodiversity conservation. Nat Commun 7:12558

Vercruysse K, Grabowski RC, Rickson RJ (2017) Suspended sediment transport dynamics in rivers: multi-scale drivers of temporal variation. Earth Sci Rev 166:38-52

Verheijen FGA, Jones RJA, Rickson RJ, Smith CJ (2009) Tolerable versus actual soil erosion rates in Europe. Earth Sci Rev 94:23-38

Verstraeten G, Prosser IP (2008) Modelling the impact of land-use change and farm dam construction on hillslope sediment delivery to rivers at the regional scale. Geomorphology 98:199-212

Vitousek PM, Mooney HA, Lubchenco J, Melillo JM (1997) Human domination of Earth's ecosystems. Science 5325:494-499

Vonk JE, Tank SE, Bowden WB, Laurion I, Vincent WF, Alekseychik P, Amyot M, Billet MF, Canário J, Cory RM, Deshpaude BN, Helbig M, Jammet M, Karlsson J, Larouche J, MacMillan G, Rautio M, Walter Anthony KM, Wickland KP (2015) Reviews and syntheses: effects of permafrost thaw on Arctic aquatic ecosystems. Biogeosciences 12:7129-7167

Vonk JE, Tank SE, Walvoord MA (2019) Integrating hydrology and biogeochemistry across frozen landscape. Nat Commun 10:5377. https://doi.org/10.1038/s41467-019-13361-5

Vörösmarty CJ, Meybeck M, Fekete B, Sharma K, Green P, Syvitski JPM (2003) Anthropogenic sediment retention: major global impact from registered river impoundments. Global Planet Change 39:169190

Vörösmarty CJ, McIntyre PB, Gessner MO, Dudgeon D, Prusevich A, Green P, Glidden S, Bunn SE, Sullivan CA, Reidy Lierman CR, Davies PM (2010) Global threats to human water security and river biodiversity. Nature 467:555-561

Wagenbrenner NS, Germino MJ, Lamb BK, Foltz RB, Robichaud PR (2011) Wind erosion of soils burned by wildfire. ISELE Paper Number 11021. International Symposium on Erosion and 
Landscape Evolution. 18-21 September 2011, Anchorage Alaska. ASABE Publication Number 711P0311cd

Wainwright J, Turnbull L, Ibrahim TG, Lexartza-Artza I, Thompson SF, Brazier RE (2011) Linking environmental régimes, space and time: interpretations of structural and functional connectivity. Geomorphology 126:387-404

Wallen IE (1951) The direct effect of turbidity on fishes. Bull Okla Agric Mech Coll 48:1-27

Walling DE (2006) Human impact on land-ocean sediment transfer by the world's rivers. Geomorph 79:192-216

Walling DE (2013) The evolution of sediment source fingerprinting investigations in fluvial systems. J Soils Sediments 13:1658-1675

Walling DE, Collins AL (2008) The catchment sediment budget as a management tool. Environ Sci Pol 11:136-143

Walling DE, Webb BW, Woodward JC (1992) Some sampling considerations in the design of effective strategies for monitoring sediment-associated transport. In: Bogen J, Walling DE, Day T (eds) Erosion and sediment transport monitoring programmes in river basins. IAHS Publ 210, IAHS Press, Wallingford, pp 279-288

Walling DE, Owens PN, Leeks GJL (1999) Fingerprinting suspended sediment sources in the catchment of the River Ouse, Yorkshire, UK. Hydrol Process 13:955-975

Walling DE, Collins AL, McMellin GK (2003a) A reconnaissance survey of the source on interstitial fine sediment recovered from salmonid spawning gravels in England and Wales. Hydrobiologia 497:91-108

Walling DE, Owens PN, Foster IDL, Lees JA (2003b) Changes in the fine sediment dynamics of the Ouse and Tweed basins in the UK over the last 100-150 years. Hydrol Process 17:3245-3269

Walters CJ (1986) Adaptive management of renewable resources. McGraw-Hill, New York

Wang S, Fu B, Piao S, Lü Y, Ciais P, Feng X, Wang Y (2016) Reduced sediment transport in the Yellow River due to anthropogenic change. Nat Geosci 9:38-41

Waters CN, Zalasiewicz J, Summerhayes C, Barnosky AD, Poirier C, Gałuszka A, Cearreta A, Edgeworth M, Ellis EC, Ellis M, Jeandel C, Leinfelder R, McNeill JR, Richter D, Steffen W, Syvitski J, Vidas D, Wagreich M, Williams M, Zhisheng A, Grinevald J, Odada E, Oreskes N, Wolfe AP (2016) The Anthropocene is functionally and stratigraphically distinct from the Holocene. Science 351:aad2622

Waters CN, Zalasiewicz J, Summerhayes C, Fairchild IJ, Rose NL, Loader NJ, Shotyk W, Cearreta A, Head MJ, Syvitski JPM, Williams M, Wagreich M, Barnosky AD, Zhisheng A, Leinfelder R, Jeandel C, Gałuszka A, do Sul Ivar JA, Gradstein F, Steffen W, McNeill JR, Wing S, Poirier C, Edgeworth M (2018) Global Boundary Stratotype Section and Point (GSSP) for the Anthropocene Series: where and how to look for potential candidates. Earth Sci Rev 178:379-429

Weech SA, Scheuhammer AM, Elliott JE, Cheng KM (2004) Mercury in fish from Pinchi Lake Region, British Columbia, Canada. Environ Pollut 131:275-286

Welch R, Jordan TR, Thomas AW (1984) A photogrammetric technique for measuring soil erosion. J Soil Water Conserv 39:191-194

Westerling AL (2016) Increasing western US forest wildfire activity: sensitivity to changes in timing of spring. Phil Trans Royal Soc B 371:20150178

Wharton G, Cotton JA, Wotton RS, Bass JAB, Heppell CM, Trimmer M, Sanders IA, Warren LL (2006) Macrophytes and suspensionfeeding invertebrates modify flows and fine sediments in the Frome and Piddle catchments, Dorset (UK). J Hydrol 330:171-184

Whicker JJ, Pinder JE III, Breshears DD (2006) Increased wind erosion for forest wildfire: implications for contaminant-related risks. J Environ Qual 35:468-478

Wilkes MA, Gittins JR, Mathers KL, Mason R, Casas-Mulet R, Vanzo D, Mckenzie M, Murray-Bligh J, England J, Gurnell A, Jones JI (2018) Physical and biological controls on fine sediment transport and storage in rivers. WIREs Water. https://doi.org/10.1002/wat2.1331
Wilkinson BH (2005) Humans as geologic agents: a deep-time perspective. Geol Soc Amer 33:161-164

Wilkinson BH, McElroy BJ (2007) The impact of humans on continental erosion and sedimentation. Geol Soc Am Bull 119:140-156

Wilkinson SN, Dougall C, Kinsey-Henderson AE et al (2014) Development of a time-stepping sediment budget model for assessing land use impacts in large river basins. Sci Total Environ 468:1210-1224

Wilkinson C, Hikuroa DCH, Macfarlane AH, Hughes MH (2020) Mātauranga Māori in geomorphology: existing frameworks, case studies and recommendations for incorporating Indigenous knowledge in Earth science. Earth Surf Dynam 8:595-618

Williams BK (2011) Adaptive management of natural resources - framework and issues. J Environ Manag 92:1346-1353

Windsor FM, Durance I, Horton AA, Thompson RC, Tyler CR, Ormerod SJ (2019) A catchment-scale perspective of plastic pollution. Glob Chang Biol 25:1207-1221

Withers PJA, Jarvie HP (2008) Delivery and cycling of phosphorus in rivers: a review. Sci Total Environ 400:379-395

Wittmann M, Zwaaftink CDG, Schmidt LS, Guðmundsson S, Palásson F, Arnalds O, Björnsson H, Thorsteinsson T, Stohl A (2017) Impact of dust on the albedo of Vatnajökull ice cap, Iceland. Cryosphere 11: $741-754$

Wohl E (2020) Rivers in the Anthropocene: the US perspective. Geomorphology. https://doi.org/10.1016/j.geomorph.2018.12.001

Wood PJ, Armitage PD (1997) Biological effects of fine sediment in the lotic environment. Environ Manag 21:2013-2217

Wu ZY, Zhao DN, Syvitski JPM, Saito Y, Zhou JQ, Wang MW (2020) Anthropogenic impacts on the decreasing sediment loads of nine major rivers in China, 1954-2015. Sci Total Environ 739:139653. https://doi.org/10.1016/j.scitotenv.2020.139653

Wynants M, Millward G, Patrick A, Taylor A, Munishi L, Mtei K, Brendonck L, Gilvear D, Boeckx P, Ndakidemi P, Blake WH (2020) Determining tributary sources of increased sedimentation in East-African Rift Lakes. Sci Total Environ 717:137206

Yu H, Chin M, Yuan T, Bian H, Remer LA, Prospero JM, Omar A, Winkler D, Yang Y, Zhang Y, Zhang Z, Zhao C (2015) The fertilizing role of African dust in the Amazon rainforest: a first multiyear assessment based on data from Cloud-Aerosol LIDAR and Infrared Pathfinder Satellite Observations. Geophys Res Lett 42:1984-1991

Yue X, Li Z, Fan J, Takeuchi N, Wang L (2020) Variation in albedo and its relationship with surface dust in Urumqi Glacier No. 1 in Tien Shan, China. Front Earth Sci 8:110. https://doi.org/10.3389/feart. 2020.00110

Yunker MBR, Macdonald RW, Vingarzan R, Mitchell RH, Goyette D, Sylvestre S (2002) PAHs in the Fraser River Basin: a critical appraisal of $\mathrm{PAH}$ ratios as indicators of $\mathrm{PAH}$ source and composition. Org Geochem 33:489-515

Zalasiewicz J, Waters CN, Summerhayes CP, Wolfe AP, Barnosky AD, Cearreta A, Crutzen P, Ellis E, Fairchild IJ, Gałuszka A, Haff P, Hajdas I, Head MJ, do Sul Ivar JA, Jeandel C, Leinfelder R, McNeill JR, Neal C, Odada E, Oreskes N, Steffen W, Syvitski J, Vidas D, Wagreich M, Williams M (2017) The Working Group on the Anthropocene: summary of evidence and interim recommendations. Anthropocene 19:55-60

Zhao Q, Wang L, Liu H, Zhang Q (2019) Runoff and sediment variation and attribution over 60 years in typical Loess Plateau basins. J Soils Sediments 19:3631-3647

Zolitschka B (1998) A 14,000 year sediment yield record from western Germany based on annually laminated lake sediments. Geomorphology 22:1-17

Publisher's note Springer Nature remains neutral with regard to jurisdictional claims in published maps and institutional affiliations. 